\title{
Near- and far-field tsunami waves, displaced water volume, potential energy and velocity flow rates by a stochastic submarine earthquake source model
}

\author{
Khaled T. Ramadan
}

Department of Basic and Applied Sciences, College of Engineering and Technology, Arab Academy for Science, Technology and Maritime Transport, P.O. Box 1029, Abu Quir Campus, Alexandria, Egypt.

\section{kramadan@aast.edu}

10 Abstract. Sources of tsunamis are non-uniform and commonly uncorrelated and very difficult to predict. The best ideal way to appear their aspects is through heterogeneous or stochastic source models which are more realistic. The effect of random fluctuation of submarine earthquake modeled by vertical time-dependent displacement of a stochastic source model is investigated on the tsunami generation and propagation waves. The noise intensity parameter controls the increase of the stochastic bottom amplitude which results in increasing the oscillations and amplitude in the free surface elevation which provides an additional contribution to tsunami waves. The $\mathrm{L}^{2}$ norm of the free surface elevation, the displaced water volume and the potential energy are examined. These quantitative information about predicting tsunami risk are useful for risk managers who decide to issue warnings and evacuation orders. The horizontal average velocity flow rates of the tsunami wave are investigated. The average velocity flow rates can provide valuable information about the stochastic bottom topography by the distinctive velocity oscillations. Flow velocity is of importance in risk assessment and hazard mitigation which may provide a clear signal of tsunami flows. Time series of the flow velocities and wave gauges under the effect the water depth of the ocean are investigated.

Keywords: Tsunami waves, Water displacement, Tsunami energy, Velocity flow rate, Dynamic bottom displacements, Stochastic process.

\section{Introduction}

Submarine earthquakes are by far the most common generator of tsunamis. They can generate tsunamis if they occur beneath an ocean, and if they result in predominantly vertical displacement. Recent catastrophic tsunami events caused by submarine earthquakes such as the Sumatran earthquake and tsunami, December 26, 2004 (Ioualalen et al. 2007; Song et al. 2008; Satake 2014) and the 2011 Tohoku-Oki earthquake and tsunami (Suppasri et al. 2013; Goda and Song 2015; Bai et al. 2015) will be remembered for its fierceness, destruction and unprecedented loss of life for a long time. Since these destructive tsunami events, efforts have been made in warning methodology, pre-disaster preparedness and basic understanding of related phenomena to help building up coastal resilience and reducing losses (Kânoğlu et al. 2015). One of the greatest uncertainties in both deterministic and probabilistic hazard assessments of tsunamis is computing sea floor deformation. This entry reviews past methodologies and current developments of seismogenic tsunami generation models (Nosov et al 2014).

A sudden upward or downward motion of a portion of the ocean floor will displace a large amount of water and generate a tsunami. A tsunami source of energy can be described by the water displacement event. The amount of water lifted above the sea level is tied up to gravitational potential energy. Much effort has been made showing quantitative information about the tsunami, including tsunami wave interaction with ocean floor bathymetric features. Nosov et al. (2014) determined the displaced water volume and the potential energy of initial elevation of the tsunami source. Satake and Tanioka (2014) summarised that the far-field tsunami surface elevations are proportional to the displaced water volume at the source, while the near-field tsunami surface elevations are determined by the potential energy of the displaced water. Satake and Kanamori (2003) computed the displaced water volume at the source and the potential energy of the uplifted water and determined that the potential energy rather than the source volume determines the tsunami amplitude. The concept of displaced water volume has also been discussed for tsunamis associated with landslides, asteroids or explosions (e.g. Fritz et al. 2003; Levin and Nosov 2008). 
Nat. Hazards Earth Syst. Sci. Discuss., https://doi.org/10.5194/nhess-2018-107

Manuscript under review for journal Nat. Hazards Earth Syst. Sci.

Discussion started: 2 May 2018

(c) Author(s) 2018. CC BY 4.0 License.

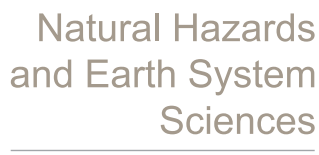

Discussions

One of the most fundamental macroscopic quantities for interpreting the size of a tsunami, as well as for understanding the physical processes of tsunami propagation and coastal impacts is the energy transmitted by tsunami waves (Tang 2012). Dutykh et al. (2012) took into account the contribution of horizontal displacements of the sea-bed displacements during the study of the evolution of the potential energy of the tsunami generated wave.

5 Dutykh and Dias (2009) computed the potential energy of the ocean by the displaced water volume from the bottom to the surface of the ocean in the domain of the dispersive linearized equations. Zhao et al. (2012) investigated the potential energy transformation during the runup and rundown processes of the leading-depression $\mathrm{N}$-wave over a plane beach using Boussinesq equations. Charvet et al. (2013) estimated the potential energy of a typical elevated wave time series during the wave runup process to measure the capability of the wave to move up the beach.

The tsunami flow velocity is a significant physical parameter to understand tsunami behaviors. To measure, predict, and compute tsunami flow velocities is of importance in risk assessment and hazard mitigation which may provide a clear signal of tsunami flows, where the arrival of the tsunami is indicated by the commencement of distinctive current velocity oscillations (Lipa 2011). This enables us to visualize the tsunami generation process, including the velocity components. Fritz et al. (2012) analyzed the tsunami current velocities and measured the

15 tsunami height in the March 2011 Tohoku, Japan, tsunami in the Kesennuma Bay by using videos recorded by survivors. Lacy et al. (2012) measured velocity profiles in northern Monterey Bay during the arrival of the 2010 Chile tsunami and found that the North-South velocity was highly correlated with the water surface elevation during the first five oscillations with a phase shift of approximately $90^{\circ}$. Lipa et al. (2012) measured the orbital velocity components to observe the tsunami signal in HF radar. They formed a time series of the average velocity, which

20 shows the characteristic oscillations produced by the tsunami. Zhao et al. (2012) obtained details on the flow field in terms of the reconstruction of the full velocity field by using Boussinesq equations. Saito (2013) derived analytical solutions for the velocity distributions in the sea to visualize the tsunami generation process. Jamin et al. (2015) performed combined measurements of the free-surface deformation and the fluid velocity field based on the role of the bottom kinematics.

25 Uniform slip dislocations will not accurately simulate details of the local tsunami wavefield and are largely insufficient to account for local tsunami amplitude variations caused by the combined effect of earthquake source complexity and inhomogeneous fault and earth structure in subduction zones. The most perfect way to appear their aspects is through heterogeneous or stochastic source models to account for source complexity which may be a key step for more realistic varying bathymetry in tsunami scenarios. The random components provide an additional

30 contribution to tsunami waves. So, it is important to take into account the random components of bottom deformation in tsunami simulation, see (Geist 2005; Dutykh et al.2013; Dias 2014). Numerous studies considered stochastic source models for the investigation of tsunami generation and propagation waves caused by submarine earthquake. Geist (2002) provided a huge range of synthetic slip distribution styles, which may be generated via the stochastic source model to gauge the fluctuation of local tsunami amplitudes in a selected area. Geist (2013)

35 supplied the maximum amplitude over time near the coast at different length shore positions for six stochastic slip realizations. Geist and Oglesby (2014b) used an assortment of stochastic models to review the observed complexity and uncertainty related with tsunami generation and propagation. Fukutani et al. (2015) implemented stochastic tsunami hazard analyses and used a logic tree to create a source model with a Tohoku-type earthquake fault zone including a random slip distribution. They showed that the influence of the number of slip distribution patterns on

40 the results of the stochastic tsunami hazard analysis greatly influenced the results of the hazard analysis for a relatively large wave height. Ruiz et al. (2015) described earthquake size for emulating numerically tsunami runup in northern Chile on the basis of generating stochastic finite fault slips. They concluded from their results that in the near field, it is very important to consider non-uniform slip distributions, because the runup is not underestimated as occurs with earthquake sources having uniform slip.

Submarine earthquakes are often represented as random phenomena, where white noise stochastic processes are adopted to properly model their frequency content (Greco et al. 2014). Numerous studies used Gaussian white noise stochastic processes to account the random components of bottom deformation in tsunami simulation, see (Omar et al. 2012; Allam et al. 2014; Omar 2014; Ramadan 2014; Ramadan et al. 2014; Ramadan et al. 2015; Ramadan et al. 2017).

50 Dynamic bottoms are often used to model the waves generated by some type of bottom motion. Numerical simulations, theory and experiments show that dynamics play an important role, where the seafloor evolves and interacts continuously with the water surface and traveled a non-negligible distance from the source region as conducted by numerous studies (e.g., Dutykh et al. 2006; Dias and Dutykh 2007; Kervella et al. 2007; Dutykh 2007; Ramadan et al. 2011). For the 2011 Tohoku tsunami, Grilli et al. (2012) showed that dynamic source models

55 yield tsunami waveforms remarkably different than instantaneous source models and concluded that dynamic models show an excellent agreement with field measurements. 
Nat. Hazards Earth Syst. Sci. Discuss., https://doi.org/10.5194/nhess-2018-107

Manuscript under review for journal Nat. Hazards Earth Syst. Sci.

Discussion started: 2 May 2018

(c) Author(s) 2018. CC BY 4.0 License.

The objective of this study is to illustrate tsunami distributions predicted in the near-and far-field caused by a dynamic displacement of a stochastic source model resulting from submarine earthquakes. Stochastic effects have been incorporated by including two Gaussian white noise processes in the $\mathrm{x}$ - and $\mathrm{y}$-direction to form a stochastic source model. Of particular interest in this study is to represent the displaced water volume, the potential energy, the

$5 \mathrm{~L}^{2}$ norm of the free surface elevation and the surface average velocity flow rates caused by the stochastic source model during the generation and propagation processes. The flow velocity and wave gauges are represented at different locations, in order to make a contribution to the improvement the warning system of tsunami arrival. The problem is solved for constant water depth using the linearized water wave theory by transforming methods (Laplace in time and Fourier in space), with the forward and inverse Laplace transforms solved analytically, and the inverse Fourier transform computed numerically by the Inverse Fast Fourier Transform (IFFT).

\section{Mathematical formulation of the linear water wave problem}

In Figure 1, the fluid is considered incompressible and the flow is irrotational in the fluid domain $\Omega=\mathrm{R}^{2} \times$ $[-h, 0]$ which is bounded above by the free surface of the ocean $z=\eta(x, y, t)$ and below by the rigid ocean floor $\mathrm{z}=-\mathrm{h}+\zeta(\mathrm{x}, \mathrm{y}, \mathrm{t})$, where $\eta(\mathrm{x}, \mathrm{y}, \mathrm{t})$ is the free surface elevation, $\mathrm{h}$ is the constant water depth and $\zeta(\mathrm{x}, \mathrm{y}, \mathrm{t})$ is the sea floor displacement function.

The linearized problem can be expressed in terms of the velocity potential $\phi(\mathrm{x}, \mathrm{y}, \mathrm{z}, \mathrm{t})$ by the Laplace equation as:

$$
\nabla^{2} \phi(\mathrm{x}, \mathrm{y}, \mathrm{z}, \mathrm{t})=0 \text { where }(\mathrm{x}, \mathrm{y}, \mathrm{z}) \in \Omega,
$$

subjected to the following boundary conditions

and

$$
\begin{aligned}
& \left.\partial_{\mathrm{z}} \phi(\mathrm{x}, \mathrm{y}, \mathrm{z}, \mathrm{t})\right|_{\mathrm{z}=0}=\partial_{\mathrm{t}} \eta(\mathrm{x}, \mathrm{y}, \mathrm{t}), \\
& \left.\partial_{\mathrm{z}} \phi(\mathrm{x}, \mathrm{y}, \mathrm{z}, \mathrm{t})\right|_{\mathrm{z}=-\mathrm{h}}=\partial_{\mathrm{t}} \zeta(\mathrm{x}, \mathrm{y}, \mathrm{t}), \\
& \left.\partial_{\mathrm{t}} \phi(\mathrm{x}, \mathrm{y}, \mathrm{z}, \mathrm{t})\right|_{\mathrm{z}=0}+\mathrm{g} \eta(\mathrm{x}, \mathrm{y}, \mathrm{t})=0 .
\end{aligned}
$$

where $\mathrm{g}$ is the acceleration due to gravity. The initial conditions are given as

$$
\phi(x, y, z, 0)=\eta(x, y, 0)=\zeta(x, y, 0)=0 .
$$

35 The linear water wave theory has been developed as a fundamental theory in questions of stability for both nearand far-field problem in the open ocean which provides an ample understanding of the physical characteristics of the tsunami, see (Jamin et al. 2015; Kervella et al. 2007; Saito and Furumura 2009; Saito T 2013; Constantin and Germain 2012; Dutykh et al. 2006. Additionally, one of the notable consequences of the linear theory is that the height distribution at the surface is not always identical to the bottom, see (Jamin et al. 2015) and (Saito 2013).

40 Linear wave theory indicates that seismic displacement by stochastic source models and tsunami generation can constructively interfere (Geist 2015). Jamin et al. (2015) computed theoretically the kinetic energy and the free surface elevation by an underwater moving bottom using the linear water wave theory and showed that the theoretical results displayed very good agreement with the experimental data. Nonlinear effects become significant and dominant as tsunami enters the run-up phase, see (Lynett and Liu 2002; Glimsdal et al. 2007; Løvholt et al.

45 2012; Samaras et al. 2015).

We applied the transform methods (Laplace in time and Fourier in space) to solve analytical the linearized problem of the long traveling free surface elevation, $\eta$, in the open ocean during the generation and propagation processes for constant water depth, $\mathrm{h}$ at resonance state (when, $\mathrm{v}=\mathrm{v}_{\mathrm{t}}=\sqrt{\mathrm{gh}}$, i.e. maximum amplification, see Ramadan et al. 2011). This solution is accurate if the depth of the water, $h$, is much greater than the amplitudes of and $\zeta$ (sea floor uplift) and $\eta$ (free surface elevation) and if the wavelength of the leading wave of the incoming tsunamis is very long in comparison with the local water depth, which is usually true for most tsunamis triggered by submarine earthquakes, slumps and slides, see (Todorovska and Trifunac 2001; Trifunac et al. 2002; Todorovska et al. 2002; Trifunac et al. 2003;Hayir 2006; Jamin et al. 2015). All these studies neglected the nonlinear terms in the boundary conditions to study the generation of the tsunami waves using the transform methods.

55 In this paper, an analytical approach was used to illustrate the tsunami wave, the $\mathrm{L}^{2}$ norms of the free surface elevation, the displaced water volume as a result of the bottom topography, the potential energy of the free surface 
elevation and the velocity flow rates in the open ocean during the generation and propagation processes for a given stochastic bottom profile $\zeta(\mathrm{x}, \mathrm{y}, \mathrm{t})$. The Laplace and Fast Fourier Transform (FFT) methods could be applied taken into account constant depths $\mathrm{h}$. After applying the Fourier-Laplace transform of the Laplace equation (1) and the boundary conditions $(2)-(4)$, and using the initial conditions in (5), the velocity potential $\bar{\phi}\left(\mathrm{k}_{1}, \mathrm{k}_{2}, \mathrm{z}, \mathrm{s}\right)$ and the free surface elevation $\bar{\eta}\left(k_{1}, k_{2}, s\right)$ are obtained, respectively as seen in Ramadan et al. (2015) as:

and

$$
\bar{\phi}\left(\mathrm{k}_{1}, \mathrm{k}_{2}, \mathrm{z}, \mathrm{s}\right)=-\frac{\mathrm{gs} \bar{s}\left(\mathrm{k}_{1}, \mathrm{k}_{2}, \mathrm{~s}\right)}{\cosh (\mathrm{kh})\left(\mathrm{s}^{2}+\omega^{2}\right)}\left(\cosh (\mathrm{kz})-\frac{\mathrm{s}^{2}}{\mathrm{gk}} \sinh (\mathrm{kz})\right),
$$

$$
\bar{\eta}\left(k_{1}, k_{2}, s\right)=\frac{s^{2} \bar{\zeta}\left(k_{1}, k_{2}, s\right)}{\cosh (k h)\left(s^{2}+\omega^{2}\right)} .
$$

10 where $\omega=\sqrt{\text { gktanh(kh) }}$ is the gravity-wave dispersion relation and $\mathrm{k}=\sqrt{\mathrm{k}_{1}{ }^{2}+\mathrm{k}_{2}{ }^{2}}$ is the wavenumber.

The above linearized solution is known as the linear water solution, where $\eta(x, y, t)$ can be obtained from equation (7) by performing the inverse transforms. The mechanism of the tsunami generation caused by submarine earthquake is initiated by a stochastic rapid uplift as shown in Figure 2b, and then propagated randomly in the lateral positive $\mathrm{x}-$ direction with time $0 \leq \mathrm{t} \leq \mathrm{t}^{*}$, to a propagated length $\mathrm{L}$ with constant velocity $\mathrm{v}$ equal to the travel velocity of the tsunami wave $v_{t}=\sqrt{g h}$ to produce a dynamic stochastic bottom displacement as shown in Figure $3 b$. In the $\mathrm{y}$-direction, the model propagates instantaneously during the time $0 \leq \mathrm{t} \leq \mathrm{t}^{*}$. The set of physical parameters used in the problem are given in Table 1.

The dynamic stochastic curvilinear slide model shown in figure 3 for $0 \leq \mathrm{t} \leq \mathrm{t}^{*}$ (generation process) is given by:

$$
\zeta(x, y, t)=\left[\zeta_{1}(x, y, t)+\zeta_{2}(x, y, t)+\zeta_{3}(x, y, t)\right]\left(1+\sigma_{x} \xi_{x}(x+50)+\sigma_{y} \xi_{y}(y+50)\right)
$$

for $-50 \leq x \leq 50+$ vt and $-50 \leq y \leq 100$.

For $\mathrm{y} \in[-50,0]$

$\zeta_{1}(x, y, t)=\left\{\begin{array}{cc}\frac{\zeta_{0}}{4}\left(1+\cos \frac{\pi}{50} \mathrm{x}\right)\left[1-\cos \frac{\pi}{50}(\mathrm{y}+50)\right], & -50 \leq \mathrm{x} \leq 0, \\ \frac{\zeta_{0}}{2}\left[1-\cos \frac{\pi}{50}(\mathrm{y}+50)\right], & 0 \leq \mathrm{x} \leq \mathrm{vt}, \\ \frac{\zeta_{0}}{4}\left[1+\cos \frac{\pi}{50}(\mathrm{x}-\mathrm{vt})\right]\left[1-\cos \frac{\pi}{50}(\mathrm{y}+50)\right], & \mathrm{vt} \leq \mathrm{x} \leq 50+\mathrm{vt},\end{array}\right.$

and for $\mathrm{y} \in[0,50]$

30

$$
\zeta_{2}(\mathrm{x}, \mathrm{y}, \mathrm{t})=\left\{\begin{aligned}
\frac{\zeta_{0}}{2}\left(1+\cos \frac{\pi}{50} \mathrm{x}\right), & -50 \leq \mathrm{x} \leq 0, \\
\zeta_{0}, & 0 \leq \mathrm{x} \leq \mathrm{vt}, \\
\frac{\zeta_{0}}{2}\left[1+\cos \frac{\pi}{50}(\mathrm{x}-\mathrm{vt})\right], & \mathrm{vt} \leq \mathrm{x} \leq 50+\mathrm{vt},
\end{aligned}\right.
$$

and for $y \in[50,100]$

$35 \quad \zeta_{3}(x, y, t)=\left\{\begin{array}{lr}\frac{\zeta_{0}}{4}\left(1+\cos \frac{\pi}{50} \mathrm{x}\right)\left[1+\cos \frac{\pi}{50}(\mathrm{y}-50)\right], & -50 \leq \mathrm{x} \leq 0, \\ \frac{\zeta_{0}}{2}\left[1+\cos \frac{\pi}{50}(\mathrm{y}-50)\right], & 0 \leq \mathrm{x} \leq \mathrm{vt}, \\ \frac{\zeta_{0}}{4}\left[1+\cos \frac{\pi}{50}(\mathrm{x}-\mathrm{vt})\right]\left[1+\cos \frac{\pi}{50}(\mathrm{y}-50)\right], & \mathrm{vt} \leq \mathrm{x} \leq 50+\mathrm{vt},\end{array}\right.$

The initial uplift of the smooth bottom topography is denoted by $\zeta_{0}$. The two independent Gaussian white noise processes are denoted by $\xi_{\mathrm{x}}(\mathrm{x})$ and $\xi_{\mathrm{y}}(\mathrm{y})$ associated with two real valued parameters $\sigma_{\mathrm{x}}, \sigma_{\mathrm{y}} \geq 0$ that control the strength of the induced noise in the $\mathrm{x}^{-}$and $\mathrm{y}$-directions, respectively and $\mathrm{v}$ is defined as the spreading velocity of 
Nat. Hazards Earth Syst. Sci. Discuss., https://doi.org/10.5194/nhess-2018-107

Manuscript under review for journal Nat. Hazards Earth Syst. Sci.

Discussion started: 2 May 2018

(c) Author(s) 2018. CC BY 4.0 License.

Natural Hazards

and Earth System

Sciences

Discussions

the stochastic bottom in the $\mathrm{x}$-direction. The initial stochastic uplift shown in Figure 2 resembles the initial elevation illustrated in Figure 2a in Nosov et al. (2011) in the source of the March 11, 2011.

The random deformation shown in Figure 3 could represent some stochastic source models in previous works done, for examples: Figures 1 and 3 in Geist (2005) which represent synthetic slip distributions from a stochastic source model, and Figure 6 in Dutykh et al. (2012) and Figure 3 in Dutykh et al. (2013), which represent random vertical bottom displacement for submarine earthquakes, and the Tohoku-type earthquake fault patterns shown in Figure 2 in Fukutani et al. (2015) who modeled different random slip distributions based on random two-dimensional Gaussian distribution. In the propagation process, for $\mathrm{t} \geq \mathrm{t}^{*}, \zeta\left(\mathrm{x}, \mathrm{y}, \mathrm{t}^{*}\right)$ is the same as equation (8) except the time parameter $\mathrm{t}$ will be substituted by $\mathrm{t}^{*}$.

10 Laplace and Fourier transforms can be applied to the bed motion described by equation (8), then substituting into equation (7) and then inverting $\bar{\eta}\left(\mathrm{k}_{1}, \mathrm{k}_{2}, \mathrm{~s}\right)$ using the inverse Laplace transform and the Convolution theorem yields $\bar{\eta}\left(k_{1}, k_{2}, t\right)$. This is verified for $0 \leq t \leq t^{*}$ where $t^{*}=L / v$ as follows:

$$
\bar{\eta}\left(k_{1}, k_{2}, t\right)=\bar{\eta}_{1}\left(k_{1}, k_{2}, t\right)+\bar{\eta}_{2}\left(k_{1}, k_{2}, t\right)+\bar{\eta}_{3}\left(k_{1}, k_{2}, t\right)
$$

See appendix A for the solution of equation (12).

We are interested in the velocity fields of the tsunami free surface elevation in the near and far field due to vertical displacement of the stochastic source model. The velocity potential can be expressed in terms of the free surface elevation from Equations (6) and (7) as:

$$
\bar{\phi}\left(\mathrm{k}_{1}, \mathrm{k}_{2}, \mathrm{z}, \mathrm{s}\right)=-\frac{\mathrm{g}}{\mathrm{s}} \bar{\eta}\left(\mathrm{k}_{1}, \mathrm{k}_{2}, \mathrm{~s}\right)\left(\cosh (\mathrm{kz})-\frac{\mathrm{s}^{2}}{\mathrm{gk}} \sinh (\mathrm{kz})\right) .
$$

Applying the inverse Laplace transform of equation (13) yields

$$
\bar{\phi}\left(\mathrm{k}_{1}, \mathrm{k}_{2}, \mathrm{z}, \mathrm{t}\right)=\frac{1}{\mathrm{k}} \sinh (\mathrm{kz}) \frac{\mathrm{d} \bar{\eta}\left(\mathrm{k}_{1}, \mathrm{k}_{2}, \mathrm{t}\right)}{\mathrm{dt}}-\mathrm{g} \cosh (\mathrm{kz}) \int_{0}^{\mathrm{t}} \bar{\eta}\left(\mathrm{k}_{1}, \mathrm{k}_{2}, \tau\right) \mathrm{d} \tau
$$

Let the horizontal velocities denoted by $\mathbf{u}(\mathrm{U}, \mathrm{V})$, and the horizontal gradient $\left(\frac{\partial}{\partial \mathrm{x}}, \frac{\partial}{\partial \mathrm{y}}\right)$ denoted by $\nabla_{\mathrm{h}}$ to evaluate the velocity components along the free surface $(\mathrm{z}=0)$. The Fourier transform parameters are denoted $\mathbf{m}=\left(\mathrm{k}_{1}, \mathrm{k}_{2}\right)$. Taking into account that horizontal velocity
components of the velocity can be defined as:

$$
\mathbf{u}(\mathrm{x}, \mathrm{y}, \mathrm{t})=\nabla_{\mathrm{h}} \phi(\mathrm{x}, \mathrm{y}, \mathrm{t})
$$

The Fourier transforms of the horizontal and vertical components of the velocity field during the generation process for $0 \leq \mathrm{t} \leq \mathrm{t}^{*}$ are given as:

$$
\begin{aligned}
\overline{\mathbf{u}}\left(\mathrm{k}_{1}, \mathrm{k}_{2}, \mathrm{t}\right) & =-i \bar{\phi}\left(\mathrm{k}_{1}, \mathrm{k}_{2}, \mathrm{t}\right) \mathbf{m} \\
& =\mathrm{i}\left[\mathrm{g} \int_{0}^{\mathrm{t}} \bar{\eta}\left(\mathrm{k}_{1}, \mathrm{k}_{2}, \tau\right) \mathrm{d} \tau\right] \mathbf{m},
\end{aligned}
$$

For $\mathrm{t} \geq \mathrm{t}^{*}$ during the propagation process, the integration $\int_{0}^{t} \bar{\eta}\left(\mathrm{k}_{1}, \mathrm{k}_{2}, \tau\right) \mathrm{d} \tau$ in equation (16) is written as $\int_{0}^{t^{*}} \bar{\eta}\left(k_{1}, k_{2}, \tau\right) d \tau+\int_{t^{*}}^{t} \bar{\eta}\left(k_{1}, k_{2}, \tau\right) d \tau$.

45 The volume of water displaced as a result of the bottom motion can be determined as the integral of the function $\eta$ taken over the entire tsunami source area. Then the total displaced water volume $\mathrm{V}(\mathrm{t})$ is given as :

$$
V(t)=\int_{R^{2}} \eta(x, y, t) d x d y
$$

50 The accumulated potential energy, $\mathrm{E}_{\mathrm{p}}(\mathrm{t})$, induced by the displacement of the free surface can be evaluated at any time by integration over the whole deformation area as: 
Nat. Hazards Earth Syst. Sci. Discuss., https://doi.org/10.5194/nhess-2018-107

Manuscript under review for journal Nat. Hazards Earth Syst. Sci.

Discussion started: 2 May 2018

(c) Author(s) 2018. CC BY 4.0 License.

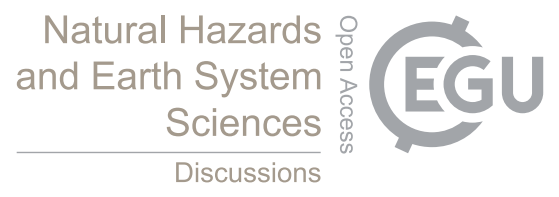

6

where $\rho$ is the water density.

$$
\mathrm{E}_{\mathrm{p}}(\mathrm{t})=\int_{\mathrm{R}^{2}} \int_{0}^{\eta} \rho \mathrm{gz} d z d x d y=\frac{1}{2} \rho g \int_{\mathrm{R}^{2}} \eta^{2} d x d y,
$$

\section{Results and Discussions}

5

Modeling earthquake-triggered tsunami generation and propagation is now standard for hazard analysis of vulnerable coastlines. The tsunami generation and propagation are illustrated by a vertical time-dependent displacement of a stochastic source model driven by two Gaussian white noise processes in the $\mathrm{x}$ - and $\mathrm{y}$-directions. The numerical results demonstrate the waveform in the near-field resulting from the stochastic source elongation to one direction (length) that vertically displaces the water column, and the wave amplitudes decaying, due to geometric spreading and dispersion in the far-field. The $\mathrm{L}^{2}$ norms of the free surface elevation normalised by the $\mathrm{L}^{2}$ norm of the bottom topography, the displaced water volume as a result of the deterministic and stochastic bottom deformations and the potential energy of the tsunami wave are examined.

\subsection{Time-Evolution during Tsunami Generation and Propagation}

Faults that produce vertical displacement change the shape of the ocean basin, which affect the entire water column and generate a tsunami. Moreover, the effect of the noise intensity on the generation of tsunami by the vertical displacement of the stochastic source model is investigated.

In Figure 4 we put in place numerical wave gauges over maximum amplitudes of the stochastic bottom topography where the largest free surface elevation are expected, and compare with the free surface elevation at the same locations over the deterministic bottom topography. The maximum amplitudes of the free surface elevation at wave gauges $(46,42),(65,42)$ and $(77,42)$ are $4.1,5.0$ and $6.1 \mathrm{~m}$, respectively in case of stochastic bottom displacement, where in case over the deterministice bottom displacement reaches a maximum amplitude of $3.6,4.4$ and $4.9 \mathrm{~m}$. Hence, the inclusion of the random noise of b
contribution to the amplitude in the free surface elevation.

We presented in Figure 5 the normalized tsunami generated and propagated amplitude for sliding length $\mathrm{L}=100$ $\mathrm{km}$ and width $\mathrm{D}=50 \mathrm{~km}$ of the deterministic and stochastic source models at different noise intensities. It can be observed how the inclusion of the noise at the lateral slopes and to the central plateau of the source model leads to an increase in the tsunami amplitude in addition to an increase in oscillations in the free surface elevation.

In Figure 5, the tsunami enters the propagation regime and due to wave divergence and dispersion, the amplitude or leading wave height decreases with the distance from the source. Accordingly, the potential energy decreases, while the kinetic energy increases, which makes the surface wave travel outward in all directions away from the source area as seen in Figures $6 c$ and $6 d$. It was observed that the leading wave crest propagate with relatively minor change with time, resulting a train of small waves behind the main wave. At $t=3 t^{*}$, the first trailing wave becomes larger than the leading one and for large propagation times, the largest amplitudes will be found in the trailing waves. The leveling of the tsunami wave due to gravity, converts the potential energy of the water into kinetic energy resulting in dispersing wave energy over a larger area, and thereby creating a propagating wave field.

Fine et al. (2013) demonstrated in Figure 5 that the propagation of long waves in the ocean due to reflections by a

40 non-uniform ocean bottom is accompanied by effects of refraction and wave scattering which leads to stochastization of the wave field. This stochastization is quite clear in the rear area in Figures 5, 6c and 6d, where the area is filled with minor waves and is transformed into a random wave field. Thus, the stochastic source model shows more oscillations in the propagated free surface elevation.

Another way to take into account the bottom deformation can be done by estimating the $\mathrm{L}^{2}$ norms of the free surface elevation normalised by the $\mathrm{L}^{2}$ norm of the bottom topography. It can be observed in Figure $7 \mathrm{~b}$ and Table 2 that the estimated $\mathrm{L}^{2}$ norms of the free surface elevation normalised by the stochastic bottom topography are smaller than in case when normalised by the deterministic bottom topography. This was due to the stochastic bottom topography results into a larger deformation than the deformation of the deterministic bottom topography. On the other hand, the estimated $\mathrm{L}^{2}$ norms of the free surface elevation in case of the stochastic bottom topography are 50 larger than in case the deterministic bottom topography as seen in Figure $7 \mathrm{a}$. Hence the estimated $\mathrm{L}^{2}$ norm can be useful in the case that there are no adequate data about the bottom topography. 
Nat. Hazards Earth Syst. Sci. Discuss., https://doi.org/10.5194/nhess-2018-107

Manuscript under review for journal Nat. Hazards Earth Syst. Sci.

Discussion started: 2 May 2018

(c) Author(s) 2018. CC BY 4.0 License.

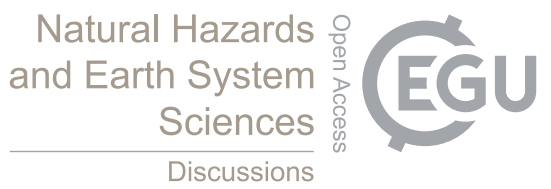

\subsection{Displaced Water Volume and Potential Energy}

We are interesting to analyze wave elevation histories using the displaced water volume as a result of the deterministic and stochastic bottom motions and the potential energy of the free surface elevation. As the vertical displacement of the deterministic and stochastic source models increases during the generation process, results in more displaced water volume in the ocean, which is proportional to the source models spreading distance as seen in Figure 8a. It can be observed that the displaced water volume of the stochastic source model for propagated length $\mathrm{L}$ $=50$ and $100 \mathrm{~km}$ reaches a maximum of 1.035 and $1.574 \mathrm{~km}^{3}$, respectively, while in case of the deterministic source model, reaches a maximum of 1.000 and $1.500 \mathrm{~km}^{3}$. This indicates that the near-field tsunami amplitudes are

10 roughly proportional to the source volume. In the propagation regime, the displaced water volume remains constant as a state of conservation of energy in an open ocean.

The amount of water lifted above the sea level is tied up to gravitational potential energy. Due to the sliding of the bottom topography which results in more displaced water volume, would raise the potential energy of the resulting wave in the generation region as seen in Figure 8b. It can be observed that the potential energy induced by the

15 stochastic source model for $\mathrm{L}=50$ and $100 \mathrm{~km}$ reaches a maximum of approximately $5.31 \times 10^{13}$ and $1.49 \times 10^{14}$ $\mathrm{J}$, respectively at rise time $\mathrm{t}=357$ and $714 \mathrm{sec}$ at the end of the generation region, and reaches a maximum of approximately $4.53 \times 10^{13}$ and $1.18 \times 10^{14} \mathrm{~J}$ in the case of the deterministic source model. Lay et al. (2005) estimated the total energy of the Indian Ocean tsunami 2004 to be equal to $4.2 \times 10^{15} \mathrm{~J}$, and Tang et al. (2012) calculated the total energy of the 2011 Tohoku earthquake and tsunami to be $3 \times 10^{15} \mathrm{~J}$.

20 As the wave height of the leading wave decreases with the distance from the source in the propagation region, the potential energy decreases. Løvholt et al.(2008) demonstrated that the energy of the leading wave crest which decreases with the propagation distance referred to the dispersion of the wave energy and migration through the tsunami wave train. This was observed in the propagation region in Figure $8 \mathrm{~b}$ where the potential energy slightly increased as a result of the tsunami wave train which comprises multiple amplitudes and frequency components behind the leading wave.

\subsection{Velocity Time Series and Wave Gauges}

We are interested in representing the time series of the average velocity flow rates $\overline{\mathrm{u}}$ and $\overline{\mathrm{v}}$, induced by the vertical displacement of deterministic and stochastic source models over the whole range of $R_{x}$ and $R_{y}$ along the free surface $(\mathrm{z}=0)$. The time series of the average velocity components provides a clear signal of tsunami flows, where the arrival of the tsunami is indicated by the commencement of distinctive current velocity oscillations as it shows the characteristic oscillations produced by the tsunami (Lipa et al. 2011; 2012). The surface average velocity flow rates are written as $\overline{\mathrm{u}}=\frac{\mathrm{Q}_{\mathrm{x}}}{\iint \mathrm{dxdy}}$ and $\overline{\mathrm{v}}=\frac{\mathrm{Q}_{\mathrm{y}}}{\iint \mathrm{dxdy}}$, where $\mathrm{Q}_{\mathrm{x}}=\iint \mathrm{udxdy}$ and $\mathrm{Q}_{\mathrm{y}}=\iint \mathrm{vdxdy}$ are called volume flow rates.

35 Figure 9 represents the time series of the surface average velocities $\bar{u}$ and $\bar{v}$ of the tsunami generated and propagated waves by the spreading deterministic and stochastic source models of propagated length $\mathrm{L}=100 \mathrm{~km}$ and width $\mathrm{D}=50 \mathrm{~km}$ at water depth $\mathrm{h}=2 \mathrm{~km}$. It can be seen in Figure 9 that the contribution of the randomness of the stochastic source model affected the average velocity flow rates by distinctive oscillations. Hence, the average velocity flow rates can provide valuable information about the ocean floor topography. In the $y$-direction, the stochastic source model propagates instantaneously as the water surface elevation builds up rapidly, and therefore the horizontal average velocity flow rate $\bar{v}$ develops a spike with drastically frequency oscillations. The oscillations in the propagation region appear due to wave dispersion and the changes in the average velocity flow rates have minimal impacts. The peak average flow rates $\overline{\mathrm{u}}$ and $\overline{\mathrm{v}}$ reaches a maximum of 0.232 and $0.160 \mathrm{~m} / \mathrm{s}$, respectively in Figure $9 \mathrm{a}$, and a maximum of 0.327 and $0.307 \mathrm{~m} / \mathrm{s}$ in Figure $9 \mathrm{~b}$. It is remarked that the average velocity flow rates is

45 typically much smaller than the tsunami phase velocity $\mathrm{v}_{\mathrm{t}}$. Present day techniques allow surface velocity amplitudes as small as $2 \mathrm{~mm} / \mathrm{s}$ to be measured.

In order to issue a tsunami warning and avoiding false alarms, it is important to detect actual generated tsunami waves by monitoring wave gauges and flow velocities. Wave gauges are deployed in order for measurement of usual sea level, which provides real-time information on the development of a tsunami following a seismic event, and thus

50 are critical for guiding the issuance of tsunami warnings Kawai et al. (2014). The flow velocities are considered as important physical parameters for understanding the mechanism of tsunami generation and for quick estimation of the tsunami intensities. Ammon et al. (2011), Iinuma et al. (2012) and Satake et al. (2013) investigated the effect of different source models on the flow velocity.

Figure 10 presents the top view of the stochastic source model at $t^{*}=\mathrm{L} / \mathrm{v}$, showing the location of two selected 55 gauges. We chose the locations of these gauges based on different altitudes of the stochastic source model. Wave gauge and current meter were used at same location to measure the wave height and flow velocity respectively. 
Nat. Hazards Earth Syst. Sci. Discuss., https://doi.org/10.5194/nhess-2018-107

Manuscript under review for journal Nat. Hazards Earth Syst. Sci.

Discussion started: 2 May 2018

(c) Author(s) 2018. CC BY 4.0 License.

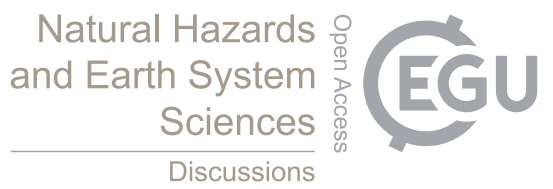

In this study, observations were made on water level and the tsunami flow velocity u at two locations, $(30,25)$ and $(77,55)$. The measurement points were chosen as a reference point for evaluating the effects of enlargement in the flow of the tsunami generation level and the flow velocity as shown in Figures 11 and 12. Figure 11 presents the evolution of the free surface elevation during the generation time at each gauge at a water depth $\mathrm{h}=2$ and $4 \mathrm{~km}$ for measuring the vertical distance to the water surface resulting from the vertical displacement of the stochastic source model. The flow velocity at a water depth $h=2$ and $4 \mathrm{~km}$ were demonstrated in Figure 12 for measuring the velocity variations of the tsunami wave. Figures 11 and 12 confirmed that the free surface elevation and the flow velocity decrease with the increase in the water depth causing an apparent shift of the free surface elevation and the flow velocity. It can be observed from Figures 11 and 12 that the flow velocity $\mathrm{u}$ is highly correlated with the free surface elevation $\eta$ with the same periodicity. In Figure 12, the maximum flow velocity for a water depth $\mathrm{h}=2 \mathrm{~km}$ attained to. 0.125 and $0.318 \mathrm{~m} / \mathrm{s}$ at the gauges $(30,25)$ and $(77,55)$, respectively, and attained to.0.056 and $0.131 \mathrm{~m} / \mathrm{s}$ for a water depth $\mathrm{h}=4 \mathrm{~km}$. For tsunami-induced currents to be detected by HF radar they must have a magnitude approaching $0.2 \mathrm{~m} / \mathrm{s}$, implying a strong coastal amplification of a tsunami wave (Godin 2004).

It is also interesting to compare the tsunami flow velocity computed with the velocity of underlying events. Flow

15 velocities of the 2004 tsunami, Indonesia were estimated peak amplitude up to $0.35 \mathrm{~m} / \mathrm{s}$, of the 2010 Chile tsunami estimated peak amplitude up to $0.36 \mathrm{~m} / \mathrm{s}$ during the largest tsunami wave (Lacy et al. 2012) and of the 2011 Tohoku tsunami for approximately peak amplitude up to $0.84 \mathrm{~m} / \mathrm{s}$ (Admire 2013).

\section{Conclusions}

20

In this study, the tsunami distributions in the near-and far-field were investigated, resulting from submarine earthquakes modeled by a dynamic displacement of a stochastic source model driven by two Gaussian white noise processes in the $\mathrm{x}$ - and $\mathrm{y}$-directions. We provided quantitative information by examining particular features of the $\mathrm{L}^{2}$ norm of the free surface elevation, the displaced water volume by the bottom deformation, the potential energy, and the average velocity flow rates to gain insight into the nature of the tsunami's genesis and propagation and to provide valuable information about the ocean floor topography. The wave gauges and the flow velocity were measured for helping tsunami warning centers to issue or cancel warnings and to make a contribution to the improvement the warning system of tsunami arrival. Through our analysis, the following understandings and conclusions were obtained:

30 (1) Increasing the noise intensity will increase the amplitude of the stochastic source model and hence increases the amplitudes and oscillations of the generated tsunami wave.

(2) The increase in the noise intensity was quite evident in the rear area of the propagated tsunami wave.

(3) Oscillations and fluctuations in the $\mathrm{L}^{2}$ norms of the free surface elevation occur during generation as well as the stochastic bottom topographical effect. Additionally, the estimated $\mathrm{L}^{2}$ norms of the free surface elevation normalised by the $\mathrm{L}^{2}$ norm of the stochastic bottom topography is smaller than when normalized by the $\mathrm{L}^{2}$ norm of the deterministic bottom topography.

(4) The inclusion of the random noise of bottom deformation provided an additional and a noticeable contribution to the displaced water volume and the potential energy of the free surface elevation.

(5) The amount of water displaced increased as the vertical displacement of the deterministic and stochastic source models increases (i.e. propagated length increases) during the generation process and then remained constant as entering the propagation regime a sort of conservation of energy.

(6) The potential energy in the near-field is increased by increasing the height of the wave due to focusing (convergence of wave energy), while in the far-field, the amplitude of the leading wave decreased with the distance from the source because of wave divergence and dispersion, and hence decreases the potential energy.

(7) When propagating more distant from the source, the potential energy slightly increased as a result of the tsunami wave train which comprises multiple amplitudes and frequency components formed immediately behind the leading wave.

(8) The time series of the average velocity flow rates can provide valuable information about the stochastic bottom topography by the distinctive velocity oscillations. This may be useful to provide warning of a tsunami approach, based on observation of velocity oscillations.

(9) In the $y$-direction, the stochastic source model propagates instantaneously, and therefore the horizontal average velocity flow rate $\bar{v}$ develops a spike with drastically frequency oscillations.

(10) In the propagation region, the wave can be considered as motionless with its velocity being weak compared to those in the generation region due to no flow outlasts resulted from the bottom motion.

55 (11) The time-varying of the flow velocity is directly proportional to the time-varying sea surface elevation induced by the generated tsunami waves. Hence, the flow velocity happens may be a good illustrative characteristic for describing the tsunami wave field throughout the movement of the ocean bottom. 
Nat. Hazards Earth Syst. Sci. Discuss., https://doi.org/10.5194/nhess-2018-107

Manuscript under review for journal Nat. Hazards Earth Syst. Sci.

Discussion started: 2 May 2018

(c) Author(s) 2018. CC BY 4.0 License.
Natural Hazards

and Earth System

Sciences

Discussions

(12) The free surface elevation and the flow velocity are in good agreement with each other. Hence, the flow velocity can be related to the free surface elevation.

(13) As the water depth increases, the peak amplitude of the free surface elevation and the flow velocity decreases.

5

\section{Appendix A. Solution for the free surface elevation}

10

The free surface elevation (12) will be solved as follows:

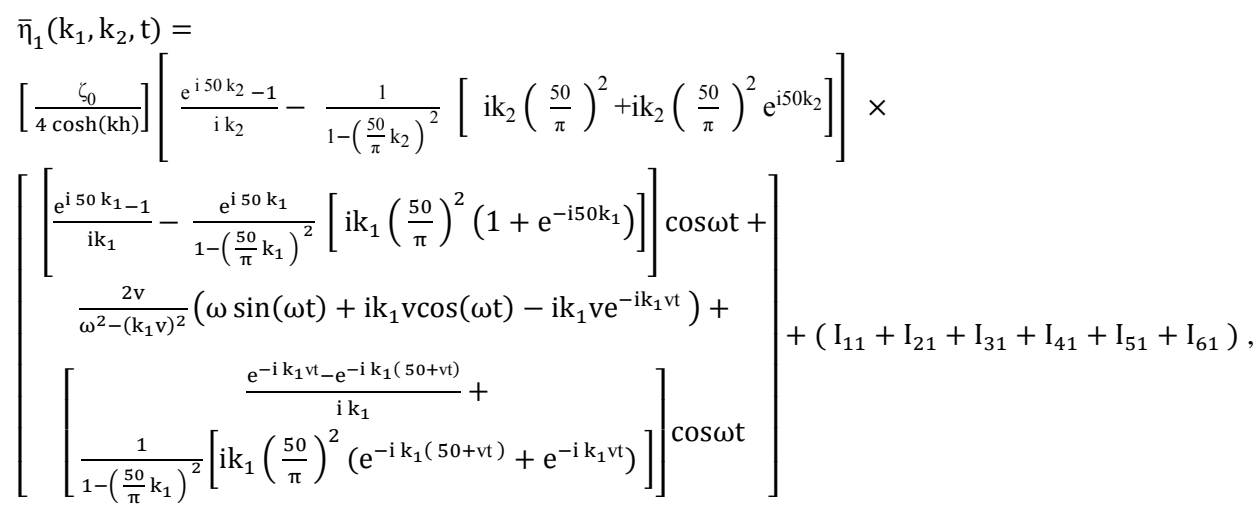

where

$$
\begin{gathered}
\mathrm{I}_{11}=\left[\frac{\zeta_{0}}{4 \cosh (\mathrm{kh})}\right] \sigma_{\mathrm{y}} \int_{-50}^{0} \mathrm{e}^{-\mathrm{i} \mathrm{k}_{2} \mathrm{y}} \mathrm{dW}(\mathrm{y})\left[\frac{\mathrm{e}^{\mathrm{i} 50 \mathrm{k}_{1}-1}}{\mathrm{ik} \mathrm{k}_{1}}-\frac{\mathrm{e}^{\mathrm{i} 50 \mathrm{k}_{1}}}{1-\left(\frac{50}{\pi} \mathrm{k}_{1}\right)^{2}}\left[\mathrm{ik}_{1}\left(\frac{50}{\pi}\right)^{2}\left(1+\mathrm{e}^{-\mathrm{i} 50 \mathrm{k}_{1}}\right)\right]\right] \cos \omega \mathrm{t}, \\
\mathrm{I}_{21}=\left[\frac{\zeta_{0} \cos \omega \mathrm{t}}{4 \cosh (\mathrm{kh})}\right]\left[\frac{\mathrm{e}^{\mathrm{i} 50 \mathrm{k}_{2}-1}}{\mathrm{i} \mathrm{k}_{2}}-\frac{1}{1-\left(\frac{50}{\pi} \mathrm{k}_{2}\right)^{2}}\left[\mathrm{ik}_{2}\left(\frac{50}{\pi}\right)^{2}+\mathrm{ik}_{2}\left(\frac{50}{\pi}\right)^{2} \mathrm{e}^{\mathrm{i} 50 \mathrm{k}_{2}}\right]\right] \sigma_{\mathrm{x}} \int_{-50}^{0} \mathrm{e}^{-\mathrm{i} \mathrm{k}_{1} \mathrm{x}} \mathrm{dW}(\mathrm{x}),
\end{gathered}
$$

$I_{31}=\left[\frac{\zeta_{0}}{4 \cosh (k h)}\right] \frac{2 v}{\omega^{2}-\left(k_{1} v\right)^{2}} \sigma_{y} \int_{-50}^{0} e^{-i k_{2} y} d W(y)\left(\omega \sin (\omega t)+i k_{1} v \cos (\omega t)-i k_{1} v^{-i k_{1} v t}\right)$,

$\mathrm{I}_{41}=\left[\frac{\zeta_{0}}{2 \cosh (\mathrm{kh})}\right] \sigma_{\mathrm{x}} \int_{0}^{\mathrm{tv}} \cos \left(\omega\left(\mathrm{t}-\frac{\mathrm{x}}{\mathrm{v}}\right)\right) \mathrm{e}^{-\mathrm{i} \mathrm{k}_{1} \mathrm{x}} \mathrm{dW}(\mathrm{x})\left[\frac{\mathrm{e}^{\mathrm{i} 50 \mathrm{k}_{2}-1}}{\mathrm{i} \mathrm{k}_{2}}-\frac{1}{1-\left(\frac{50}{\pi} \mathrm{k}_{2}\right)^{2}}\left[\mathrm{ik} \mathrm{k}_{2}\left(\frac{50}{\pi}\right)^{2}+\mathrm{ik}_{2}\left(\frac{50}{\pi}\right)^{2} \mathrm{e}^{\mathrm{i} 50 \mathrm{k}_{2}}\right]\right]$

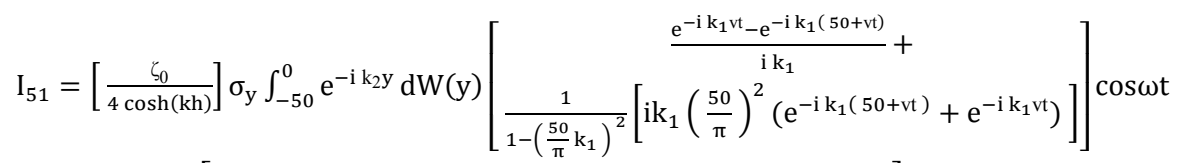

$\mathrm{I}_{61}=\left[\frac{\zeta_{0} \cos \omega \mathrm{t}}{4 \cosh (\mathrm{kh})}\right]\left[\frac{\mathrm{e}^{\mathrm{i} 50 \mathrm{k}_{2}-1}}{\mathrm{i} \mathrm{k}_{2}}-\frac{1}{1-\left(\frac{50}{\pi} \mathrm{k}_{2}\right)^{2}}\left[\mathrm{ik}_{2}\left(\frac{50}{\pi}\right)^{2}+\mathrm{ik}_{2}\left(\frac{50}{\pi}\right)^{2} \mathrm{e}^{\mathrm{i} 50 \mathrm{k}_{2}}\right]\right] \sigma_{\mathrm{x}} \int_{\mathrm{vt}}^{50+\mathrm{vt}} \mathrm{e}^{-\mathrm{i} \mathrm{k} 1_{1} \mathrm{x}} \mathrm{dW}(\mathrm{x})$.

The same can be done for $\bar{\eta}_{2}\left(k_{1}, k_{2}, t\right)$ and $\bar{\eta}_{3}\left(k_{1}, k_{2}, t\right)$.

$\xi_{\mathrm{x}}(\mathrm{x})$ and $\xi_{\mathrm{y}}(\mathrm{y})$ are the two independent Gaussian white noise processes which are random processes with zero mean and are the formal derivative of the standard Wiener processes $\mathrm{W}(\mathrm{x})$ and $\mathrm{W}(\mathrm{y})$, respectively. Thus, the integrals in (A1) is a stochastic integral that can be considered as Itô integrals, see Kloeden and Platen (1992); Omar et al. (2011). 
Nat. Hazards Earth Syst. Sci. Discuss., https://doi.org/10.5194/nhess-2018-107

Manuscript under review for journal Nat. Hazards Earth Syst. Sci.

Discussion started: 2 May 2018

(c) Author(s) 2018. CC BY 4.0 License.

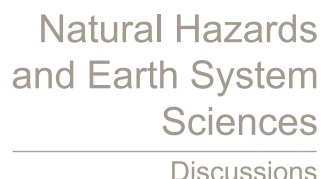

Discussions

(c) (1)

Substituting equations $\bar{\eta}_{1}\left(\mathrm{k}_{1}, \mathrm{k}_{2}, \mathrm{t}\right), \quad \bar{\eta}_{2}\left(\mathrm{k}_{1}, \mathrm{k}_{2}, \mathrm{t}\right)$ and $\bar{\eta}_{3}\left(\mathrm{k}_{1}, \mathrm{k}_{2}, \mathrm{t}\right)$ into equation (2.12) gives $\bar{\eta}\left(\mathrm{k}_{1}, \mathrm{k}_{2}, \mathrm{t}\right)$ for $0 \leq \mathrm{t} \leq \mathrm{t}^{*}$.In case for $\mathrm{t} \geq \mathrm{t}^{*}, \bar{\eta}\left(\mathrm{k}_{1}, \mathrm{k}_{2}, \mathrm{t}\right)$ will have the expression as equation (2.12) except the term resulting from the convolution theorem, i.e.

$\int_{t-t^{*}}^{t} \cos (\omega \tau) e^{-i k_{1} v(t-\tau)} d \tau=\frac{1}{\omega^{2}-\left(k_{1} v\right)^{2}}\left[\begin{array}{c}\omega \sin \omega t+i k_{1} v \cos \omega t \\ -e^{-i k_{1} v t^{*}}\left(\omega \sin \omega\left(t-t^{*}\right)+i k_{1} v \cos \omega\left(t-t^{*}\right)\right)\end{array}\right]$,

instead of

10

$\int_{0}^{t} \cos (\omega \tau) e^{-i k_{1} v(t-\tau)} d \tau=\frac{1}{\omega^{2}-\left(k_{1} v\right)^{2}}\left(\omega \sin \omega t+i k_{1} v \cos \omega t-i k_{1} v e^{-i k_{1} v t}\right)$,

and

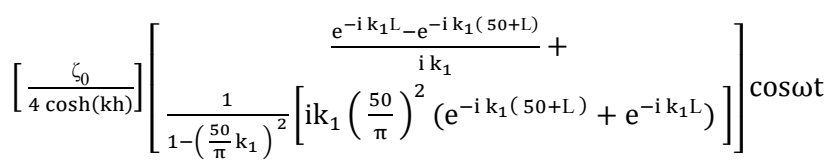

instead of $\left[\frac{\zeta_{0}}{4 \cosh (k h)}\right]\left[\begin{array}{c}\frac{e^{-i k_{1} v t}-e^{-i k_{1}(50+v t)}}{i k_{1}}+ \\ \frac{1}{1-\left(\frac{50}{\pi} k_{1}\right)^{2}}\left[i k_{1}\left(\frac{50}{\pi}\right)^{2}\left(e^{-i k_{1}(50+v t)}+e^{-i k_{1} v t}\right)\right]\end{array}\right] \operatorname{cos\omega t}$

and $\int_{0}^{L} \cos \left(\omega\left(t-\frac{x}{v}\right)\right) e^{-i k_{1} x} d W(x) \quad$ instead of $\int_{0}^{t v} \cos \left(\omega\left(t-\frac{x}{v}\right)\right) e^{-i k_{1} x} d W(x)$

and $\int_{L}^{50+L} e^{-i k_{1} x} d W(x)$ instead of $\int_{v t}^{50+v t} e^{-i k_{1} x} d W(x)$

20

Finally, $\eta(x, y, t)$ is evaluated using the double inverse Fourier transform of $\bar{\eta}\left(k_{1}, k_{2}, t\right)$

$$
\eta(x, y, t)=\frac{1}{(2 \pi)^{2}} \int_{-\infty}^{\infty} e^{i k_{2} y}\left[\int_{-\infty}^{\infty} e^{i k_{1} x} \bar{\eta}\left(k_{1}, k_{2}, t\right) d k_{1}\right] d k_{2} .
$$

This inversion is computed by using the Matlab FFT algorithm. 
Nat. Hazards Earth Syst. Sci. Discuss., https://doi.org/10.5194/nhess-2018-107

Manuscript under review for journal Nat. Hazards Earth Syst. Sci.

Discussion started: 2 May 2018

(c) Author(s) 2018. CC BY 4.0 License.

\section{References}

Admire, A.R.: Observed and modeled tsunami current velocities on California's north coast. PhD thesis, Humboldt State University, 2013.

5 Allam, A.A., Omar, M.A., and Ramadan, K.T.; Three-Dimensional Modeling of Tsunami Generation and Propagation under the Effect of Stochastic Seismic Fault Source Model in Linearized Shallow-Water Wave Theory, ISRN Applied Mathematics, 1-27, http://doi.org/10.1155/2014/874230, 2014.

Ammon, C.J., Lay, T., Kanamori, H., and Cleveland, M.: A rupture model of the 2011 off the Pacific coast of Tohoku Earthquake, Earth, Planets and Space, 63, 693-696, http://doi:10.5047/eps.2011.05.015, 2011.

Bai, Y., Yamazaki, Y., and Cheung, K.F.: Interconnection of multi-scale standing waves across the Pacific Basin from the 2011 Tohoku Tsunami, Ocean Modelling, 92, 183-197, http://doi:10.1016/j.ocemod.2015.06.007, 2015.

Charvet, I., Eames, I., and Rossetto, T.: New tsunami runup relationships based on long wave experiments, Ocean Modelling, 69, 79-92, http://dx.doi.org/10.1016/j.ocemod.2013.05.009, 2013.

Constantin, A. and Germain, P.: On the open sea propagation of water waves generated by a moving bed, Phil. Trans. R. Soc. A, 370, 1587-1601, http://doi:10.1098/rsta.2011.0443, 2012.

Dias, F. and Dutykh, D.: Dynamics of tsunami waves. Extreme man-made and natural hazards in dynamics of structures, Springer Netherlands, 201-224, http://doi:10.1007/978-1-4020-5656-7_8, 2007.

Dias, F., Dutykh, D., O'Brien, L., Renzi, E., and Stefanakis, T.: On the modelling of tsunami generation and tsunami inundation, Procedia IUTAM 10, 338-355, http://doi:10.1016/j.piutam.2014.01.029, 2014.

Dutykh, D., Dias, F., and Kervella, Y.: Linear theory of wave generation by a moving bottom, C. R. Acad. Sci. Paris, Ser. I, 343, 499-504, https://doi.org/10.1016/j.crma.2006.09.016, 2006.

Dutykh, D., Dias, F., and Kervella, Y.: Linear theory of wave generation by a moving bottom C.R. Acad. Sci. Paris 343, 499-504, http://doi:10.1016/j.crma.2006.09.016, 2006.

Dutykh. D.: Mathematical modelling of tsunami waves, $\mathrm{PhD}$ thesis, École normale supérieure de Cachan-ENS Cachan, 2007.

Dutykh, D. and Dias, F.: Energy of tsunami waves generated by bottom motion, Proc. R. Soc. A, 465, $725-744$. http://doi:10.1098/rspa.2008.0332, 2009.

Dutykh, D., Mitsotakis, D., Chubarov, L.B., and Shokin, Y.I.: On the contribution of the horizontal sea-bed displacements into the tsunami generation process, Ocean Modelling, 56, 43-56, http://doi:10.1016/j.ocemod.2012.07.002, 2012.

Dutykh, D., Mitsotakis, D., Gardeil, X., and Dias, F.: On the use of the finite fault solution for tsunami generation problems, Theoretical and Computational Fluid Dynamics, 27, 177-199, http://doi:10.1007/s00162-011$0252-8,2013$.

Fine, I.V., Kulikov, E.A., and Cherniawsky, J.Y.: Japan's 2011 tsunami: Characteristics of wave propagation from observations and numerical modeling, Pure and Applied Geophysics, 170, 1295-1307, http://doi:10.1007/s00024-012-0555-8, 2013.

Fritz, H.M., Hager, W.H., and Minor, H.E.: Landslide generated impulse waves. 2. Hydrodynamic impact craters, Experiments in Fluids 35, 520-532, https://doi.org/10.1007/s00348-003-0660-7, 2003.

Fritz, H.M., Phillips, D.A., Okayasu, A., Shimozono, T., Liu, H., Mohammed, F., Skanavis, V., Synolakis, C.E., and Takahashi, T.: The 2011 Japan tsunami current velocity measurements from survivor videos at Kesennuma Bay using LiDAR, Geophysical Research Letter, 39, L00G23. http://doi:10.1029/2011GL050686, 2012.

Fukutani, Y., Suppasri, A., and Imamura, F.: Stochastic analysis and uncertainty assessment of tsunami wave height using a random source parameter model that targets a Tohoku-type earthquake fault. Stochastic Environmental Research and Risk Assessment, 29, 1763-1779. http://doi:10.1007/s00477-014-0966-4, 2015

Geist, E.L.: Complex earthquake rupture and local tsunamis, J. Geophys. Res. 107, 2086-2100, https://doi.org/10.1029/2000JB000139, 2002.

Geist, E.L.: Rapid tsunami models and earthquake source parameters: far-field and local applications, ISET J. Earthq. Technol., 42, 127-136, 2005.

Geist, E.L.: Near-Field Tsunami Edge Waves and Complex Earthquake Rupture, Pure and Applied Geophysics, 170, 1475-1491. http://doi:10.1007/s00024-012-0491-7, 2013.

Geist, E.L. and Oglesby, D.D: Earthquake Mechanism and Seafloor Deformation for Tsunami Generation. Encyclopedia of Earthquake Engineering, Springer-Verlag Berlin Heidelberg, 1-17, http://doi:10.1007/9783-642-36197-5_296-1, 2014a. 
Nat. Hazards Earth Syst. Sci. Discuss., https://doi.org/10.5194/nhess-2018-107

Manuscript under review for journal Nat. Hazards Earth Syst. Sci.

Discussion started: 2 May 2018

(c) Author(s) 2018. CC BY 4.0 License.

Geist, E.L. and Oglesby, D.: Tsunamis: Stochastic Models of Occurrence and Generation Mechanisms, Encyclopedia of Complexity and Systems Science, Springer-Verlag New York, 1-29, http://doi:10.1007/978-3-642-27737-5_595-1, 2014b.

Geist, E.L.: Non-linear resonant coupling of tsunami edge waves using stochastic earthquake source models, Geophysical Journal International, 204, 878-891, http://doi:10.1029/2003JC002030, 2015

Glimsdal, S., Pedersen, G.K., Langtangen, H.P., Shuvalov, V., and Dypvik, H.: Tsunami generation and propagation from the Mjølnir asteroid impact, Meteoritics \& Planetary Science, 42, 1473-1493, https://doi.org/10.1111/j.1945-5100.2007.tb00586.x, 2007

Goda, K. and Song, J.: Uncertainty modeling and visualization for tsunami hazard and risk mapping: a case study for the 2011 Tohoku earthquake, Stochastic Environmental Research and Risk Assessment, 1-15, https://doi.org/10.1007/s00477-015-1146-x, 2015.

Godin, O.A.: Air-sea interaction and feasibility of tsunami detection in the open ocean, Journal of Geophysical Research: Oceans 109(C5), http://doi:10.1029/2003JC002030, 2004.

Greco, R., Fiore, A., and Marano, G.C.: The Role of Modulation Function in Nonstationary Stochastic Earthquake Model, J. Earthq. Tsunami, 8, 1450015, http://doi:10.1142/s1793431114500158, 2014.

Grilli, S.T., Harris, J.C., Tajalli Bakhsh, T.S., Masterlark, T.L., Kyriakopoulos, C., Kirby, J.T., and Shi, F.: Numerical Simulation of the 2011 Tohoku Tsunami Based on a New Transient FEM Co-seismic Source: Comparison to Far- and Near-Field Observations, Pure and Applied Geophysics, 170, 1333-1359, http://doi:10.1007/s00024-012-0528-y, 2012.

Hayir, A.: The near-field tsunami amplitudes caused by submarine landslides and slumps spreading in two orthogonal directions, Ocean engineering, 33, 654-664, https://doi.org/10.1016/j.oceaneng.2005.05.010, 2006.

Iinuma, T., Hino, R., Kido, M., Inazu, D., Osada, Y., Ito, Y., Ohzono, M., Tsushima, H., Suzuki, S., Fujimoto, H., and Miura, S.: Coseismic slip distribution of the 2011 off the Pacific Coast of Tohoku Earthquake (M9.0) refined by means of seafloor geodetic data, J. Geophysical. Res., 117, B07409, http://doi:10.1029/2012JB009186, 2012.

Ioualalen, M., Asavanant, J., Kaewbanjak, N., Grilli, S.T., Kirby, J.T., and Watts, P.: Modeling the 26 December 2004 Indian Ocean tsunami: Case study of impact in Thailand, Journal of Geophysical Research: Oceans, 112, 1978-2012, http://doi:10.1029/2006JC003850, 2007.

Jamin, T., Gordillo, L., Ruiz-Chavarría, G., Berhanu, M., and Falcon, E.: Experiments on generation of surface waves by an underwater moving bottom, Proc. R. Soc., A, 471, 20150069, http://doi:10.1098/rspa.2015.0069, 2015.

Kânoğlu, U., Titov, V., Bernard, E., and Synolakis, C.: Tsunamis: bridging science, engineering and society. Phil. Trans. R.Soc. A 373: 20140369, https://doi.org/10.1098/rsta.2014.0369, 2015.

Kawai, H., Satoh, M., Kawaguchi, K., and Seki, K.: 2010 Chile and 2011 Tohoku tsunami profiles measured by GPS buoys and coastal wave and tide gauges in a nationwide ocean wave information network for ports and harbors. Journal of Waterway, Port, Coastal, and Ocean Engineering, 140, 135-14, https://doi.org/10.1061/(ASCE)WW.1943-5460.0000235, 2014.

Kervella, Y., Dutykh, D., and Dias, F.: Comparison between three-dimensional linear and nonlinear tsunami generation models. Theoretical and Computational Fluid Dynamics, 21, 245-269. https://doi.org/10.1007/s00162-007-0047-0, 2007.

Kloeden, P.E. and Platen, E.: Numerical Solution of Stochastic Differential Equations, Springer-Verlag Berlin, pp. $548,1992$.

Lacy, J.R., Rubin, D.M., and Buscombe, D.: Currents, drag, and sediment transport induced by a tsunami. Journal of Geophysical Research: Oceans, 117(C9). http://doi:10.1029/2012JC007954, 2012.

Lay, T., Kanamori, H., Ammon, C.J., Nettles, M., Ward, S.N., Aster, R.C., Beck, S.L., Bilek, S.L., Brudzinski, M.R., Butler, R., and DeShon, H.R.: The Great Sumatra-Andaman Earthquake of 26 December 2004, Science, 308, 1127-1133, http://doi: 10.1126/science.1112250, 2005.

Levin,, B.W. and Nosov, M.A.: Physics of Tsunamis. Springer-Verlag, 2008.

Lipa, B., Barrick, D., Saitoh, S.I., Ishikawa, Y., Awaji, T., Largier, J., and Garfield, N.: Japan tsunami current flows observed by HF radars on two continents, Remote Sensing, 3, 1663-1679, http://doi:10.3390/rs3081663, 2011.

Lipa, B., Isaacson, J., Nyden, B., and Barrick, D.: Tsunami arrival detection with high frequency (HF) radar, Remote Sensing, 4, 1448-1461, http://doi:10.3390/rs4051448, 2012.

Løvholt, F., Pedersen, G., and Gisler, G.: Oceanic propagation of a potential tsunami from the La Palma Island, Journal of Geophysical Research, 113, C09026, http://doi:10.1029/2007JC004603, 2008. 
Nat. Hazards Earth Syst. Sci. Discuss., https://doi.org/10.5194/nhess-2018-107

Manuscript under review for journal Nat. Hazards Earth Syst. Sci.

Discussion started: 2 May 2018

(c) Author(s) 2018. CC BY 4.0 License.

Løvholt, F., Pedersen, G., Bazin, S., Kühn, D., Bredesen, R.E., and Harbitz, C.: Stochastic analysis of tsunami runup due to heterogeneous coseismic slip and dispersion, Journal of Geophysical Research: Oceans, 117:C3, https://doi.org/10.1029/2011JC007616, 2012.

Lynett, P. and Liu, P.L.F.: A numerical study of submarine-landslide-generated waves and run-up, Proc. R. Soc. Lond. A, 458, 2885-2910, http://doi:10.1098/rspa.2002.0973, 2002.

Nosov, M.A., Kolesov, S.V., and Levin, B.W.: Contribution of horizontal deformation of the seafloor into tsunami generation near the coast of Japan on March 11, 2011, Doklady Earth Sciences, 441, 1537-1542, http://doi:10.1134/S1028334X11110079, 2011.

Nosov, M.A., Bolshakova, A.V., and Kolesov, S.V.: Displaced water volume, potential energy of initial elevation, and tsunami intensity: Analysis of recent tsunami events, Pure and Applied Geophysics, 171, 3515-3525, https://doi.org/10.1007/s00024-013-0730-6, 2014.

Omar, M.A., Aboul-Hassan, A., and Rabia, S.I.: The composite Milstein methods for the numerical solution of Ito stochastic differential equations, Journal of Computational and Applied Mathematics, 235, 2277-2299, http://doi:10.1016/j.cam.2010.10.026, 2011.

Omar, M.A., Allam, A.A., and Ramadan, K.T.: Generation and Propagation of Tsunami Wave under the Effect of Stochastic Bottom, International Conference on Mathematics Trends and Development (ICMTD12), (2012)

Omar, M.A., Ramadan, K.T., and Allam, A.A.: Linearized Shallow-water Wave Theory of Tsunami Generation and Propagation by Three-dimensional Stochastic Seismic Bottom Topography, Research Journal of Applied Sciences, Engineering and Technology, 7, 4035-4055, http://doi:10.19026/rjaset.7.765, 2014.

Ramadan, K.T., Hassan, H.S., and Hanna, S.N.: Modeling of tsunami generation and propagation by a spreading curvilinear seismic faulting in linearized shallow-water wave theory, Applied Mathematical Modelling, 35, 61-79, http://doi:10.1016/j.apm.2010.05.007, 2011.

Ramadan, K.T.: Tsunami Generation and Propagation by a Curvilinear Stochastic source fault model in Linearized Shallow-Water Wave Theory, European Journal of Scientific Research, 124(3), 328-358, (2014)

Ramadan, K.T., Omar, M.A., and Allam, A.A.: Modeling of tsunami generation and propagation under the effect of stochastic submarine landslides and slumps spreading in two orthogonal directions, Ocean Engineering, 75, 90-111, http://doi:10.1016/j.oceaneng.2013.11.013, 2014.

Ramadan, K.T., Allam, A.A., and Omar, M.A.: Near-and far-field tsunami amplitudes by a moving curvilinear stochastic submarine slide shape based on linearized water wave theory, Ocean Engineering, 109, 34-59, https://doi.org/10.1016/j.oceaneng.2015.08.064, 2015.

Ramadan, K.T., Omar, M.A., and Allam, A.A.: Tsunami Energy, Ocean-Bottom Pressure, and Hydrodynamic Force from Stochastic Bottom Displacement, Pure and Applied Geophysics, 174, 1315-1330, http://doi:10.1007/s00024-016-1463-0, 2017.

Ruiz, J.A., Fuentes, M., Riquelme, S., Campos, J., and Cisternas, A.: Numerical simulation of tsunami runup in northern Chile based on non-uniform k- 2 slip distributions, Natural Hazards, 79, 1177-1198, http://doi:10.1007/s11069-015-1901-9, 2015.

Saito, T. and Furumura, T.: Three-dimensional tsunami generation simulation due to sea-bottom deformation and its interpretation based on the linear theory, Geophysical Journal International, 178, 877-888, http://doi:10.1111/j.1365-246x.2009.04206.x, 2009.

Saito, T.: Dynamic tsunami generation due to sea-bottom deformation: Analytical representation based on linear potential theory, Earth, Planets and Space, 65, 1411-1423, http://doi:10.5047/eps.2013.07.004, 2013.

Samaras, A.G., Karambas, T.V., and Archetti, R.: Simulation of tsunami generation, propagation and coastal inundation in the Eastern Mediterranean, Ocean Science, 11, 643-655, http://doi:10.5194/os-11-643, (2015)

Satake, K. and Kanamori, H.: Abnormal tsunamis caused by the June 13, 1984, Torishima, Japan, earthquake, Journal of Geophysical Research: Solid Earth, 96, 19933-19939. https://doi.org/10.1029/91JB01903, 1991.

Satake, K. and Tanioka, Y.: The July 1998 Papua New Guinea Earthquake: mechanism and quantification of unusual tsunami generation, Pure and Applied Geophysics, 160, 2087-2188, https://doi.org/10.1007/s00024003-2421-1, 2003.

Satake, K., Fujii, Y, Harada T., and Namegaya, Y.: Time and space distribution of coseismic slip of the 2011 Tohoku earthquake as inferred from tsunami waveform data, Bulletin of the seismological society of America, 103, 1473-1492, http://doi:10.1785/0120120122, 2013.

Satake, K.: Advances in earthquake and tsunami sciences and disaster risk reduction since the 2004 Indian ocean tsunami, Geoscience Letters, 1, 1-13, http://doi:10.1186/s40562-014-0015-7, 2014.

Song, Y.T., Fu, L.L., Zlotnicki, V., Ji, C., Hjorleifsdottir, V., Shum, C.K., and Yi, Y.: The role of horizontal impulses of the faulting continental slope in generating the 26 December 2004 tsunami, Ocean Modelling, 20, 362-379, http://doi:10.1016/j.ocemod.2007.10.007, 2008. 
Nat. Hazards Earth Syst. Sci. Discuss., https://doi.org/10.5194/nhess-2018-107

Manuscript under review for journal Nat. Hazards Earth Syst. Sci.

Discussion started: 2 May 2018

(c) Author(s) 2018. CC BY 4.0 License.

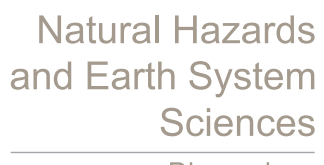

Discussions

Suppasri, A., Shuto, N., Imamura, F., Koshimura, S, Mas E., and Yalciner, A.C.: Lessons learned from the 2011 Great East Japan tsunami: performance of tsunami countermeasures, coastal buildings, and tsunami evacuation in Japan, Pure and Applied Geophysics, 170, 993-1018, http://doi:10.1007/s00024-012-0511-7, 2013.

5 Tang, L., Titov, V.V., Bernard, E.N., Wei, Y., Chamberlin, C.D., Newman, J.C., Mofjeld, H.O., Arcas, D., Eble, M.C., Moore, C., Uslu, B., Pells, C., Spillane, M., Wright, L., and Gica, E.: Direct energy estimation of the 2011 Japan tsunami using deep-ocean pressure measurements, Journal of Geophysical Research: Oceans, 117(C8), https://doi.org/10.1029/2011JC007635, 2012.

Trifunac, M.D., Hayir, A., and Todorovska, M.I.: Was Grand Banks event of 1929 a slump spreading in two directions?, Soil Dynamics and Earthquake Engineering, 22, 349-360, https://doi.org/10.1016/S02677261(02)00029-5, 2002.

Trifunac, M.D., Hayir, A., and Todorovska, M.I.: A note on tsunami caused by submarine slides and slumps spreading in one dimension with nonuniform displacement amplitudes, Soil Dynamics and Earthquake Engineering, 23, 41-52, https://doi.org/10.1016/S0267-7261(02)00211-7, 2003.

Todorovska, M.I. and Trifunac, M.D.: Generation of tsunamis by a slowly spreading uplift of the sea floor, Soil Dynamics and Earthquake Engineering, 21, 151-167, https://doi.org/10.1016/S0267-7261(00)00096-8, 2001.

Todorovska, M.I., Hayir, A., and Trifunac, M.D.: A note on tsunami amplitudes above submarine slides and slumps, Soil Dynamics and Earthquake Engineering, 22, 129-141, https://doi.org/10.1016/S0267-7261(01)00058-6, 2002.

Zhao, X., Wang B., and Liu, H.: Characteristics of tsunami motion and energy budget during runup and rundown processes over a plane beach, Physics of Fluids, 24, 1-25, http://doi:10.1063/1.4729597, 2012. 
Nat. Hazards Earth Syst. Sci. Discuss., https://doi.org/10.5194/nhess-2018-107

Manuscript under review for journal Nat. Hazards Earth Syst. Sci.

Discussion started: 2 May 2018

(c) Author(s) 2018. CC BY 4.0 License.

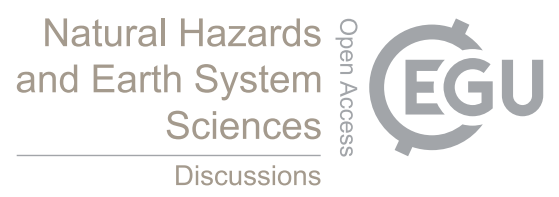

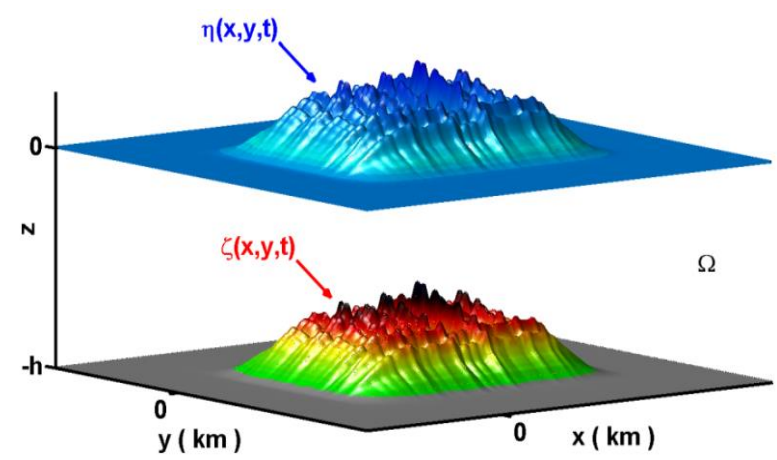

Figure 1. Fluid domain and coordinate system for an instantaneous movement of the stochastic curvilinear source model. 
Nat. Hazards Earth Syst. Sci. Discuss., https://doi.org/10.5194/nhess-2018-107

Manuscript under review for journal Nat. Hazards Earth Syst. Sci.

Discussion started: 2 May 2018

(c) Author(s) 2018. CC BY 4.0 License.

(c) (i)

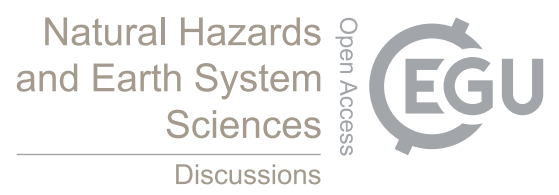

16

5

10

15

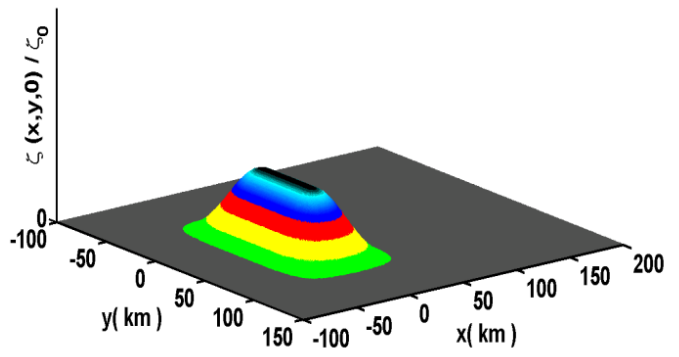

(a)

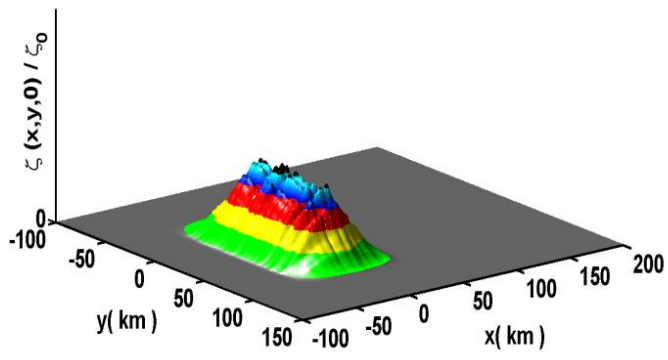

(b)

Figure 2. Normalized initial bottom topography represented by (a) deterministic uplift (b) stochastic uplift. 
Nat. Hazards Earth Syst. Sci. Discuss., https://doi.org/10.5194/nhess-2018-107

Manuscript under review for journal Nat. Hazards Earth Syst. Sci.

Discussion started: 2 May 2018

(c) Author(s) 2018. CC BY 4.0 License.

(c) (i)

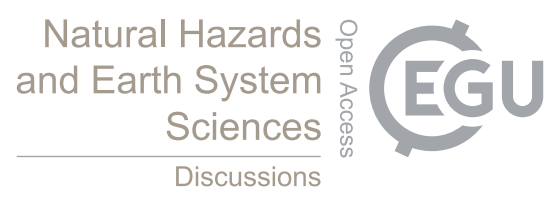

15

20

25

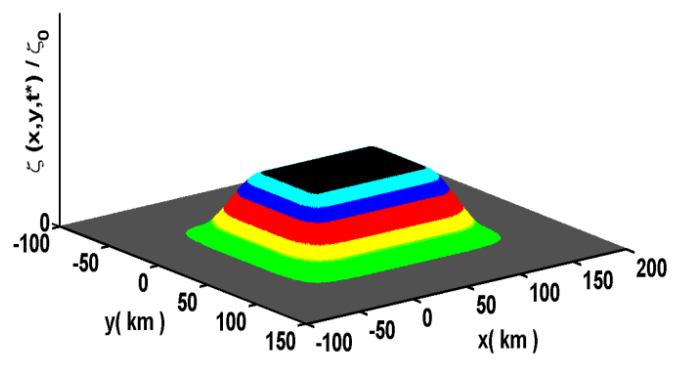

(a)

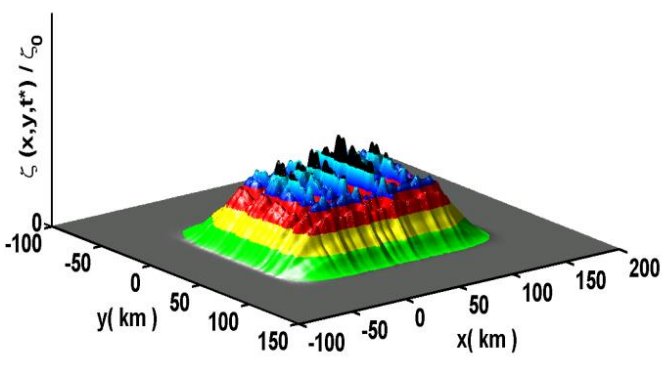

(b)

Figure 3. Normalized bottom deformation represented by the spreading (a) deterministic source model (b) stochastic 30 source model at $\mathrm{t}=\mathrm{t}^{*}=\mathrm{L} / \mathrm{v}=100 / \mathrm{v}$. 
Nat. Hazards Earth Syst. Sci. Discuss., https://doi.org/10.5194/nhess-2018-107

Manuscript under review for journal Nat. Hazards Earth Syst. Sci.

Discussion started: 2 May 2018

(c) Author(s) 2018. CC BY 4.0 License.
Natural Hazards and Earth System

Sciences

Discussions

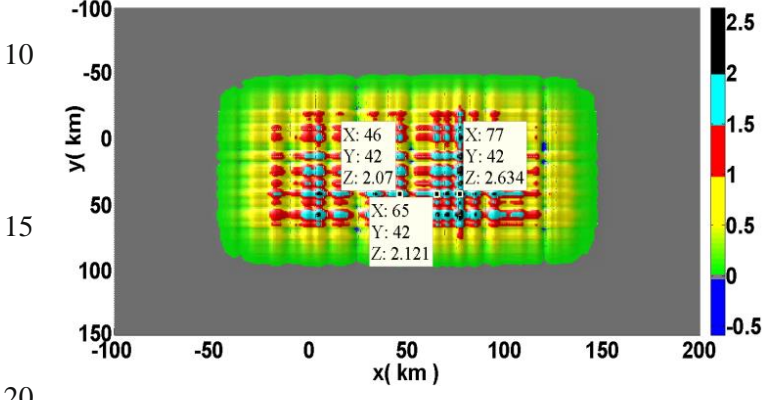

(a)

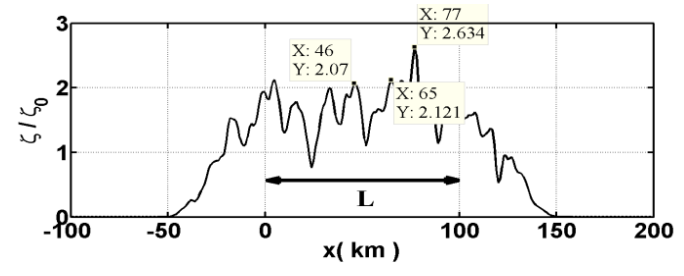

(b)

35

40

45

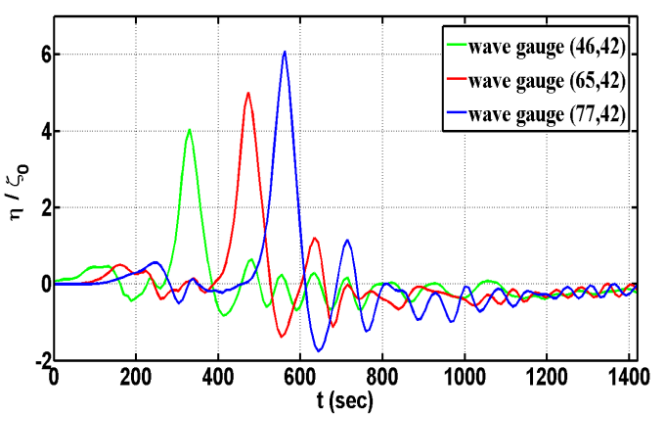

(c)

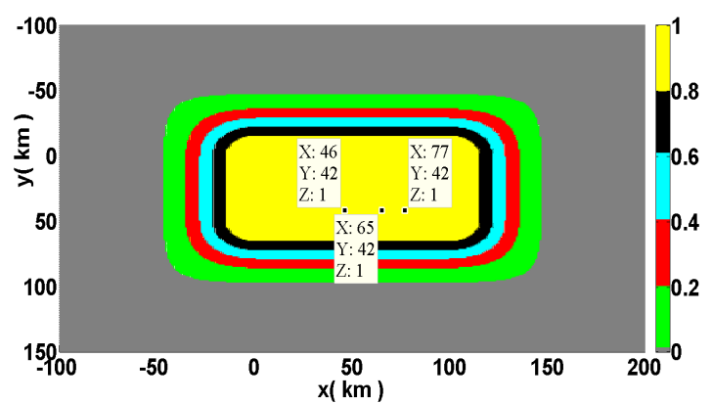

(d)

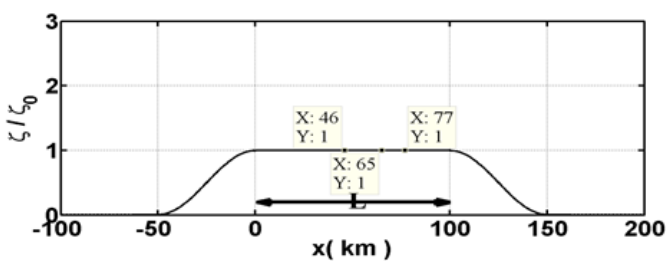

(e)

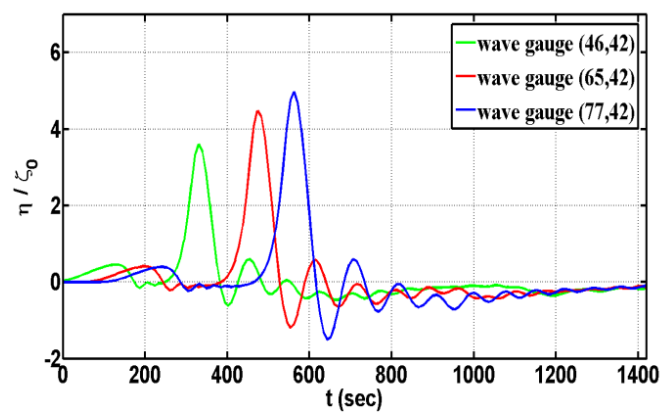

(f)

Figure 4. Free surface elevation $\eta(x, y, t)$ at different location of wave gauges along (a) top view and (b) side view of maximum values of the stochastic deformation amplitude and (d) top view and (e) side view of deterministic deformation amplitude at constant water depth $\mathrm{h}=2 \mathrm{~km}$, propagated length $\mathrm{L}=100 \mathrm{~km}$ and total width equal to 150 $\mathrm{km}$, 
Nat. Hazards Earth Syst. Sci. Discuss., https://doi.org/10.5194/nhess-2018-107

Manuscript under review for journal Nat. Hazards Earth Syst. Sci.

Discussion started: 2 May 2018

(c) Author(s) 2018. CC BY 4.0 License.
Natural Hazards

and Earth System

Sciences

Discussions
5

10

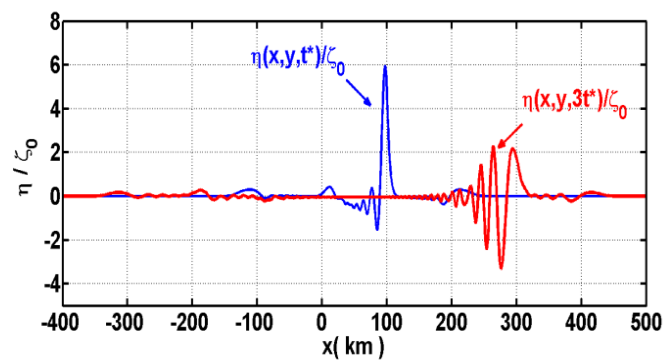

(a)

15

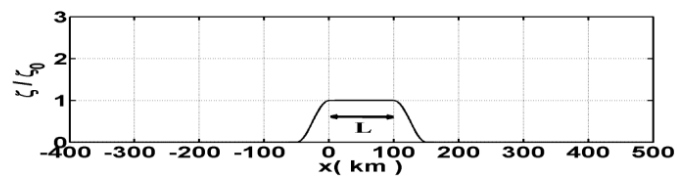

(b)

20

25

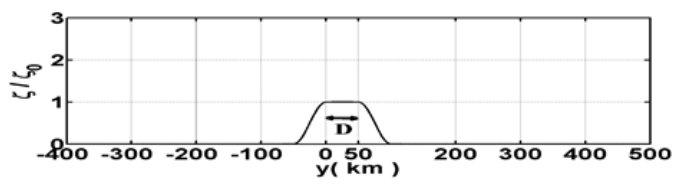

(c)

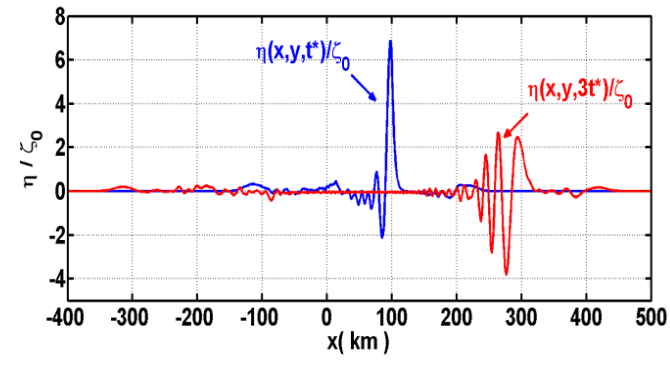

(d)

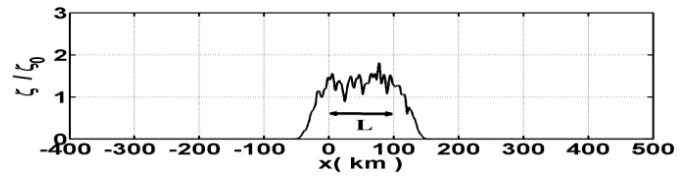

(e)

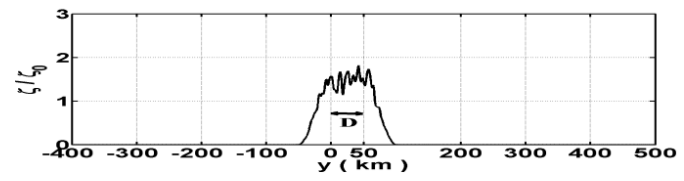

(f)

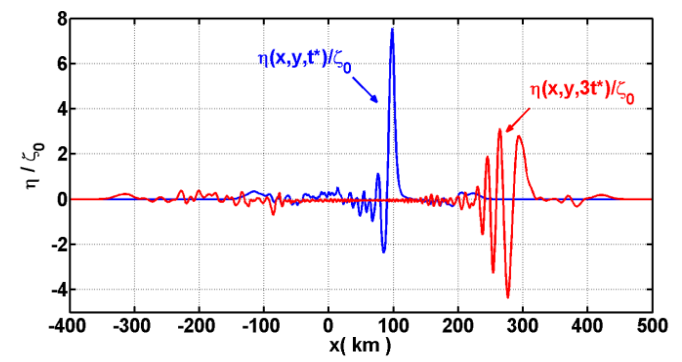

(g)

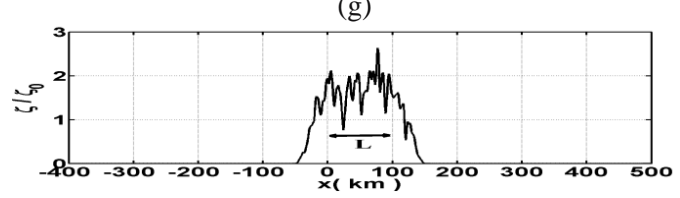

(h)

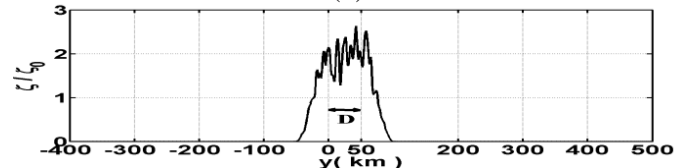

(i)

Figure 5. The normalized tsunami generated (blue) and propagated (red) amplitude at time $t=t^{*}$ and $3 t^{*}$, respectively by the (b) deterministic bottom topography in $\mathrm{x}$-direction and (c) deterministic bottom topography in $\mathrm{y}$ direction, (e) stochastic bottom topography at $\sigma_{\mathrm{x}}=\sigma_{\mathrm{y}}=0.4$ in the x-direction and (f) stochastic bottom topography at $\sigma_{\mathrm{x}}=\sigma_{\mathrm{y}}=0.4$ in the y-direction, (h) stochastic bottom topography at $\sigma_{\mathrm{x}}=\sigma_{\mathrm{y}}=0.8$ in the $\mathrm{x}$ direction and (i) stochastic bottom topography at $\sigma_{\mathrm{x}}=\sigma_{\mathrm{y}}=0.8$ in the y-direction for propagated length $\mathrm{L}=100$ $\mathrm{km}$ and width $\mathrm{D}=50 \mathrm{~km}$ at constant water depth $\mathrm{h}=2 \mathrm{~km}$. 
Nat. Hazards Earth Syst. Sci. Discuss., https://doi.org/10.5194/nhess-2018-107

Manuscript under review for journal Nat. Hazards Earth Syst. Sci.

Discussion started: 2 May 2018

(c) Author(s) 2018. CC BY 4.0 License.
Natural Hazards 웅 and Earth System

Sciences

Discussions

5

10

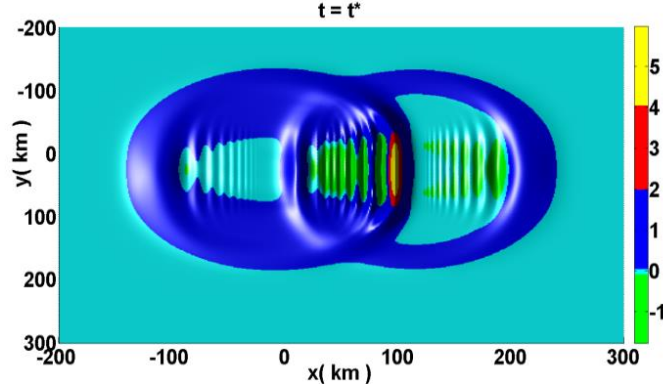

(a)

20

25

30

35

40

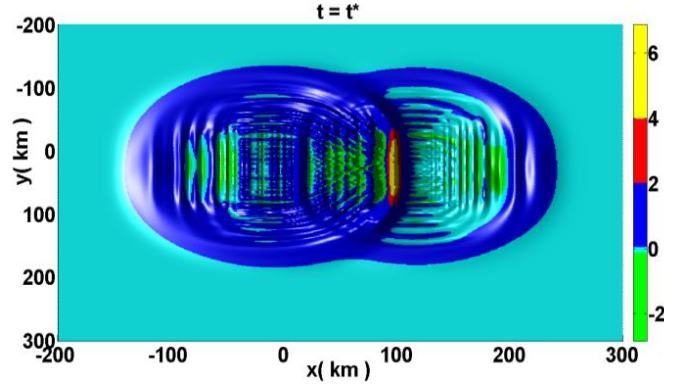

(b) source model and (d) the stochastic source model at time $t=3 t^{*}$.

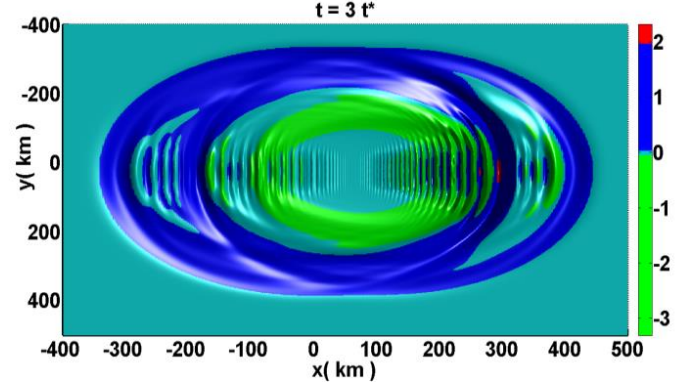

(c)

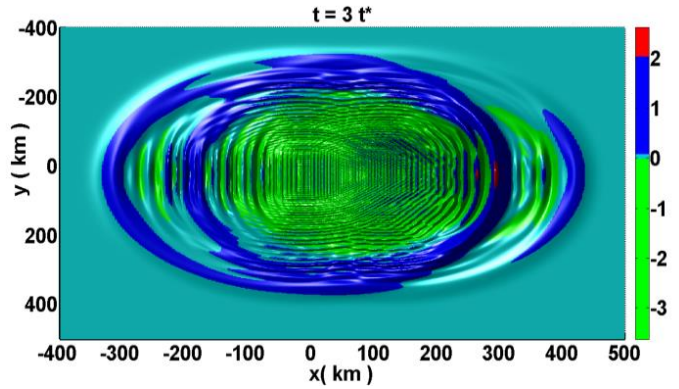

(d)

Figure 6. Top view of the normalized tsunami generated waveform by (a) the deterministic source model and (b) the stochastic source model at time $\mathrm{t}=\mathrm{t}^{*}$ and the normalized tsunami propagated waveform by (c) the deterministic 
Nat. Hazards Earth Syst. Sci. Discuss., https://doi.org/10.5194/nhess-2018-107

Manuscript under review for journal Nat. Hazards Earth Syst. Sci.

Discussion started: 2 May 2018

(c) Author(s) 2018. CC BY 4.0 License.

(c) (i)

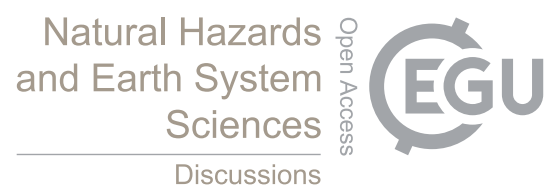

5

10

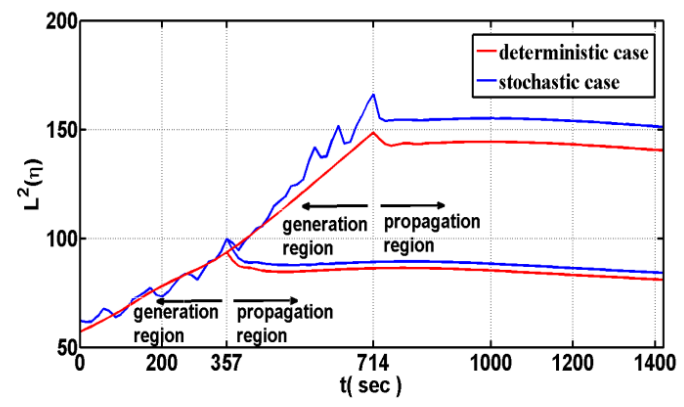

(a)

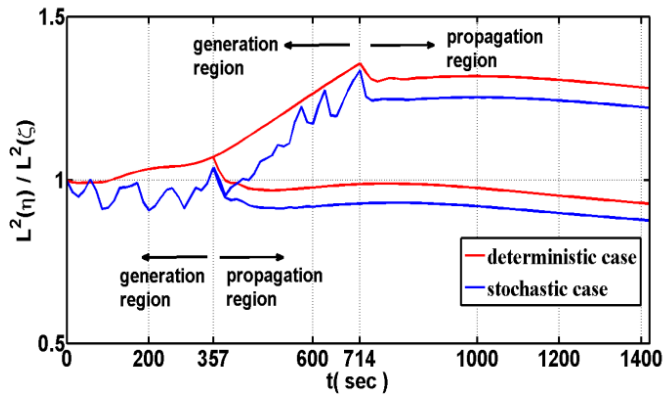

(b)

Figure 7. $\mathrm{L}^{2}$ norms of (a) the free surface elevation (b) the free surface elevation normalised by the $\mathrm{L}^{2}$ norm of the deterministic and stochastic bottom topography during the generation and propagation processes for $\mathrm{L}=50$ and 100 $\mathrm{km}$ at rise time $\mathrm{t}=357$ and $714 \mathrm{sec}$, respectively. 
Nat. Hazards Earth Syst. Sci. Discuss., https://doi.org/10.5194/nhess-2018-107

Manuscript under review for journal Nat. Hazards Earth Syst. Sci.

Discussion started: 2 May 2018

(c) Author(s) 2018. CC BY 4.0 License.

(c) (i)

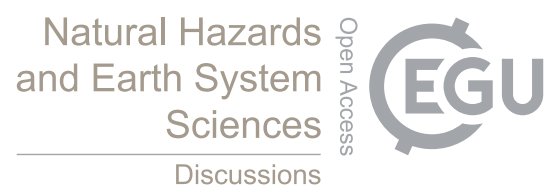

10

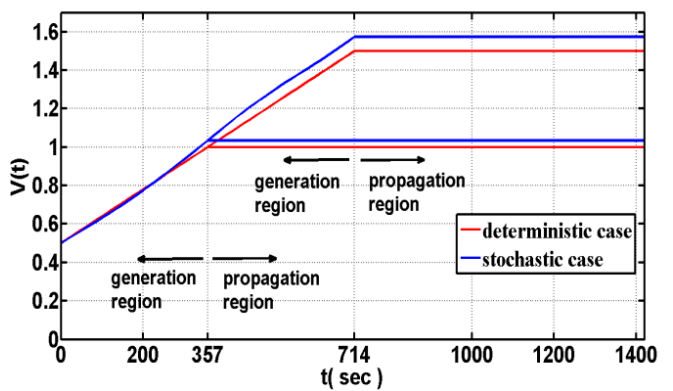

(a)

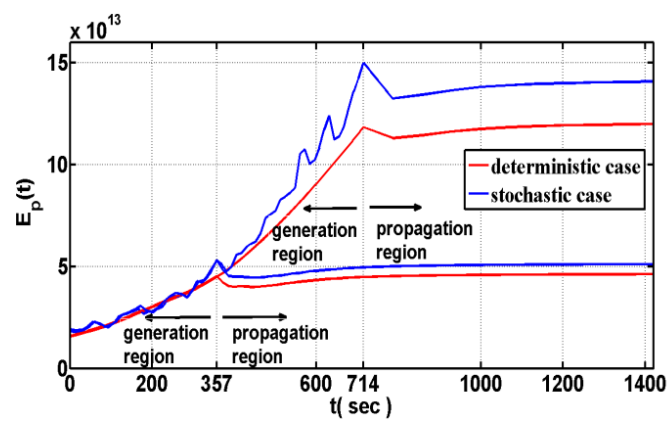

(b)

Figure 8. Time evolution of (a) the displaced water volume as a result of the deterministic and stochastic bottom displacement to propagated lengths $\mathrm{L}=50$ and $100 \mathrm{~km}$ at rise time $\mathrm{t}=357$ and $714 \mathrm{sec}$, respectively and width $\mathrm{D}=$ $50 \mathrm{~km}$ and (b) the corresponding potential energy of the free surface elevation during the generation and propagation processes. 
Nat. Hazards Earth Syst. Sci. Discuss., https://doi.org/10.5194/nhess-2018-107

Manuscript under review for journal Nat. Hazards Earth Syst. Sci.

Discussion started: 2 May 2018

(c) Author(s) 2018. CC BY 4.0 License.

(c) (i)

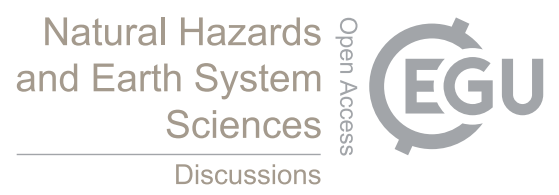

Discussions

10

15

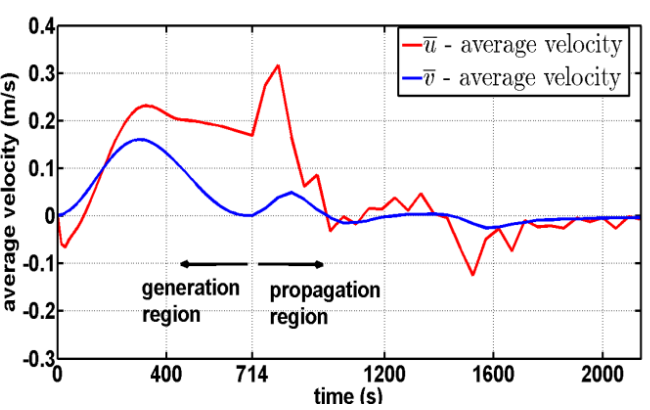

(a)

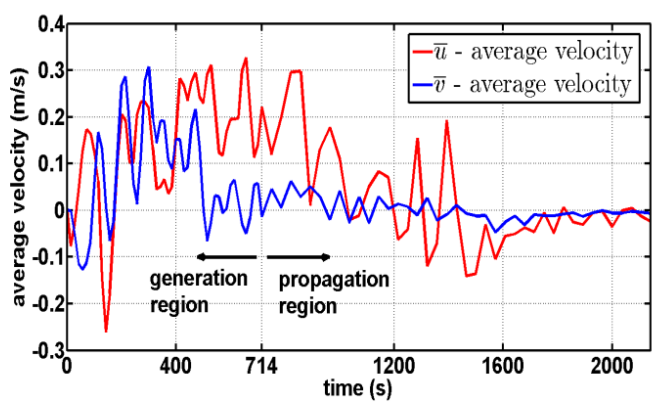

(b)

25

Figure 9. Time evolution of the surface average velocities $\overline{\mathrm{u}}$ and $\overline{\mathrm{v}}$ during the generation and propagation processes induced by the vertical displacement of the (a) deterministic source model and by (b) the stochastic source model at water depth $\mathrm{h}=2 \mathrm{~km}$. 
Nat. Hazards Earth Syst. Sci. Discuss., https://doi.org/10.5194/nhess-2018-107

Manuscript under review for journal Nat. Hazards Earth Syst. Sci.

Discussion started: 2 May 2018

(c) Author(s) 2018. CC BY 4.0 License.

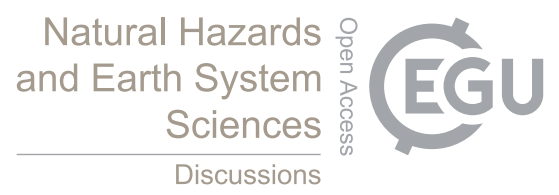

(c) (i)

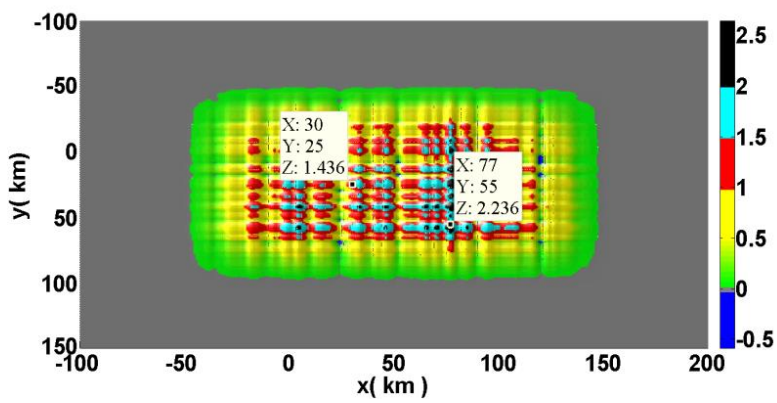

Figure 10. Location of the two numerical wave gauges superposed with the stochastic bottom displacement, with the following coordinates $(\mathrm{x}, \mathrm{y})$ in $\mathrm{km}:(30,25)$ and $(77,55)$. 
Nat. Hazards Earth Syst. Sci. Discuss., https://doi.org/10.5194/nhess-2018-107

Manuscript under review for journal Nat. Hazards Earth Syst. Sci.

Discussion started: 2 May 2018

(c) Author(s) 2018. CC BY 4.0 License.

\section{(c) (1)}

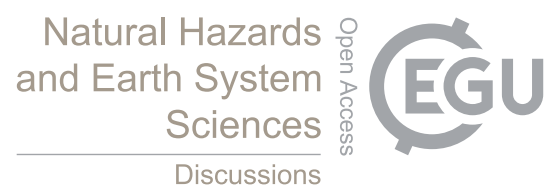

15

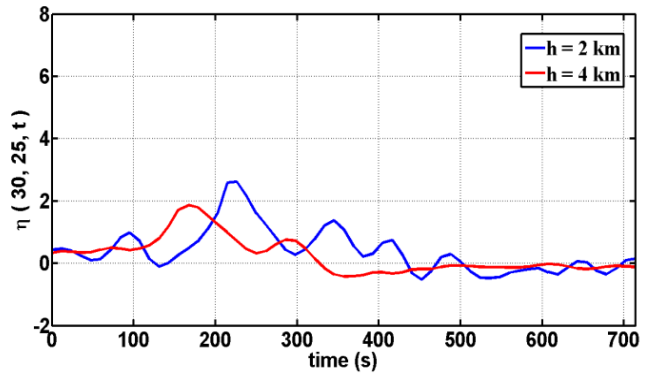

(a) Gauge at $(30,25)$

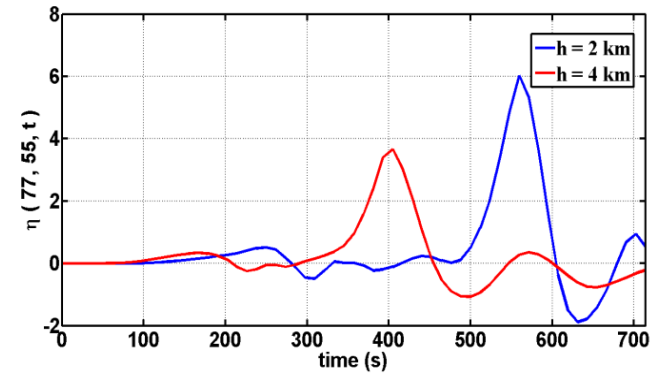

(b) Gauge at $(77,55)$

Figure 11. Generated free surface elevation $\eta(x, y, t)$ along the two selected gauges located in figure 10 at water depth $\mathrm{h}=2$ and $4 \mathrm{~km}$ from time $\mathrm{t}=0$ to $\mathrm{t}^{*}=\mathrm{L} / \sqrt{2 \mathrm{~g}}=714 \mathrm{sec}$. 
Nat. Hazards Earth Syst. Sci. Discuss., https://doi.org/10.5194/nhess-2018-107

Manuscript under review for journal Nat. Hazards Earth Syst. Sci.

Discussion started: 2 May 2018

(c) Author(s) 2018. CC BY 4.0 License.

\section{(c) (1)}

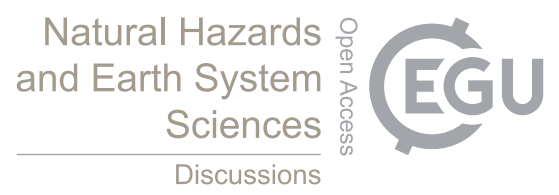

15

20

25

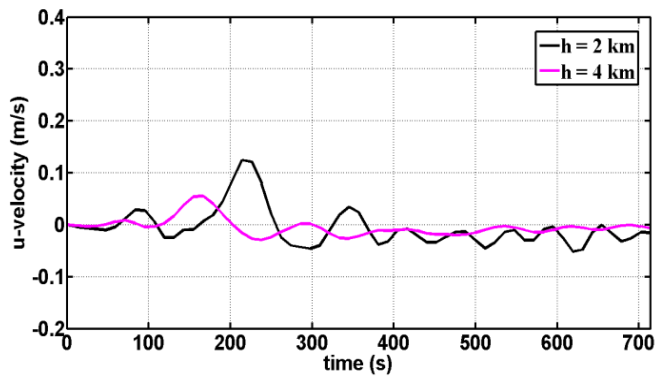

(a) $(30,25)$

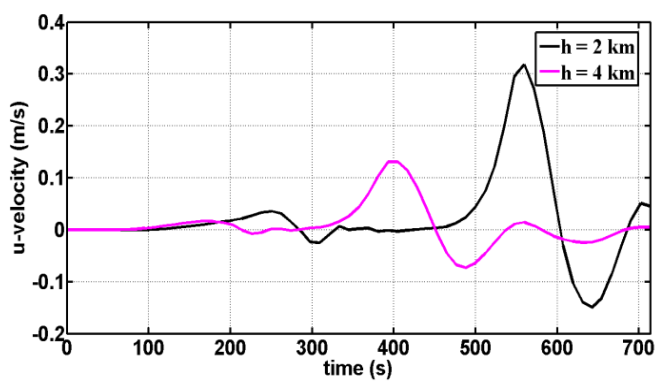

(b) $(77,55)$

Figure 12. Flow velocity u along the two selected gauges located in figure 10 at water depth $\mathrm{h}=2$ and $4 \mathrm{~km}$ from time $\mathrm{t}=0$ to $\mathrm{t}^{*}=\mathrm{L} / \sqrt{2 \mathrm{~g}}=714 \mathrm{sec}$. 
Nat. Hazards Earth Syst. Sci. Discuss., https://doi.org/10.5194/nhess-2018-107

Manuscript under review for journal Nat. Hazards Earth Syst. Sci.

Discussion started: 2 May 2018

(c) Author(s) 2018. CC BY 4.0 License.

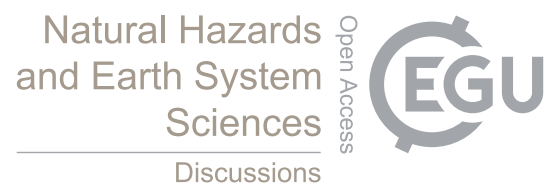

Discussions

Table 1. Parameters used in the analytical solution of the problem

\begin{tabular}{lc}
\hline \multicolumn{1}{c}{ Parameters } & Values for the bottom displacement \\
\hline -Source width, $\mathrm{D}, \mathrm{km}$ & 50 \\
- Propagated length $\mathrm{L}, \mathrm{km}$ & 100 \\
-Water depth (uniform), $\mathrm{h}, \mathrm{km}$ & 2 \\
-Acceleration due to gravity, $\mathrm{g}, \mathrm{km} / \mathrm{sec}^{2}$ & 0.0098 \\
-Tsunami velocity, $\mathrm{v}_{\mathrm{t}}=\sqrt{\mathrm{gh}}, \mathrm{km} / \mathrm{sec}$ & 0.14 \\
-Spreading velocity, $\mathrm{v}, \mathrm{km} / \mathrm{sec}$ & 0.14 \\
- Rise time, $\mathrm{t}^{*}$ & $\mathrm{t}^{*}=\frac{\mathrm{L}}{\mathrm{v}}=714 \mathrm{sec}=11.9 \mathrm{~min}$
\end{tabular}

5

10

15 
Nat. Hazards Earth Syst. Sci. Discuss., https://doi.org/10.5194/nhess-2018-107

Manuscript under review for journal Nat. Hazards Earth Syst. Sci.

Discussion started: 2 May 2018

(c) Author(s) 2018. CC BY 4.0 License.

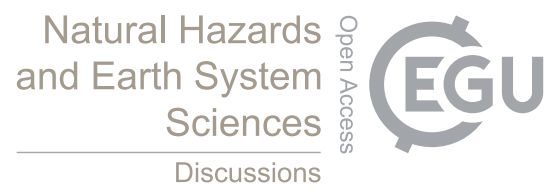

(c) (i)

28

Table 2. Estimated $\mathrm{L}^{2}$ norms of the generated free surface elevation and the normalised by the $\mathrm{L}^{2}$ norm of the deterministic and stochastic bottom topographies at different rise times

\begin{tabular}{|l|l|l|l|l|}
\hline \multirow{2}{*}{ Rise time $(\mathrm{t})$} & \multicolumn{2}{|c|}{$\mathrm{L}^{2}(\eta)$} & \multicolumn{2}{c|}{$\mathrm{L}^{2}(\eta) / \mathrm{L}^{2}(\zeta)$} \\
\cline { 2 - 5 } & deterministic & stochastic & deterministic & stochastic \\
\hline $\mathrm{t}=0.1 \mathrm{t}^{*}$ & 108.8 & 119.8 & 0.992 & 0.961 \\
$\mathrm{t}=0.2 \mathrm{t}^{*}$ & 111.2 & 121.0 & 1.015 & 0.977 \\
$\mathrm{t}=0.3 \mathrm{t}^{*}$ & 113.5 & 113.8 & 1.036 & 0.919 \\
$\mathrm{t}=0.4 \mathrm{t}^{*}$ & 114.4 & 113.0 & 1.044 & 0.912 \\
$\mathrm{t}=0.5 \mathrm{t}^{*}$ & 117.3 & 128.5 & 1.070 & 1.038 \\
$\mathrm{t}=0.6 \mathrm{t}^{*}$ & 122.9 & 124.2 & 1.122 & 1.003 \\
$\mathrm{t}=0.7 \mathrm{t}^{*}$ & 129.3 & 133.1 & 1.180 & 1.075 \\
$\mathrm{t}=0.8 \mathrm{t}^{*}$ & 136.0 & 151.7 & 1.421 & 1.225 \\
$\mathrm{t}=0.9 \mathrm{t}^{*}$ & 142.4 & 148.3 & 1.300 & 1.197 \\
$\mathrm{t}=\mathrm{t}^{*}$ & 148.6 & 161.2 & 1.356 & 1.306 \\
\hline
\end{tabular}

5

10 